\title{
Use of Wild Relatives and Closely Related Species to Adapt Common Bean to Climate Change
}

\author{
Timothy G. Porch ${ }^{1, *}$, James S. Beaver ${ }^{2}$, Daniel G. Debouck ${ }^{3}$, Scott A. Jackson ${ }^{4}$, James D. Kelly ${ }^{5}$ \\ and Hannes Dempewolf ${ }^{6}$
}

1 USDA-ARS, Tropical Agriculture Research Station (TARS), 2200 P. A. Campos Ave., Suite 201, Mayagüez 00680-5470, Puerto Rico

2 Department of Crop \& Agro-Environmental Sciences, University of Puerto Rico, Mayagüez Campus, Call Box 9000, Mayagüez 00681-9000, Puerto Rico; E-Mail: James.Beaver@upr.edu

3 Genetic Resources Program, International Center for Tropical Agriculture (CIAT), A.A. 6713, Cali, Colombia; E-Mail: d.debouck@cgiar.org

4 Center for Applied Genetic Technologies and the Institute for Plant Breeding, Genetics and Genomics, University of Georgia, 111 Riverbend Rd., Athens, GA 30602, USA; E-Mail: sjackson@uga.edu

5 Plant, Soil and Microbial Sciences, Michigan State University, 1066 Bogue St., East Lansing, MI 48824, USA; E-Mail: kellyj@msu.edu

6 Global Crop Diversity Trust, Platz Der Vereinten Nationen 7, Bonn 53113, Germany;

E-Mail: hannes.dempewolf@croptrust.org

* Author to whom correspondence should be addressed; E-Mail: timothy.porch@ars.usda.gov;

Tel.: +1-787-831-3435; Fax: +1-787-831-3386.

Received: 28 January 2013; in revised form: 16 April 2013 / Accepted: 2 May 2013 /

Published: 10 May 2013

Abstract: Common bean (Phaseolus vulgaris L.) is an important legume crop worldwide. However, abiotic and biotic stress limits bean yields to $<600 \mathrm{~kg} \mathrm{ha}^{-1}$ in low-income countries. Current low yields result in food insecurity, while demands for increased yields to match the rate of population growth combined with the threat of climate change are significant. Novel and significant advances in genetic improvement using untapped genetic diversity available in crop wild relatives and closely related species must be further explored. A meeting was organized by the Global Crop Diversity Trust to consider strategies for common bean improvement. This review resulted from that meeting and considers our current understanding of the genetic resources available for common bean improvement and the progress that has been achieved thus far through introgression of genetic diversity from wild relatives of common bean, and from closely related species, including: P. acutifolius, 
P. coccineus, $P$. costaricensis and $P$. dumosus. Newly developed genomic tools and their potential applications are presented. A broad outline of research for use of these genetic resources for common bean improvement in a ten-year multi-disciplinary effort is presented.

Keywords: abiotic stress; disease resistance; crop improvement; genetic diversity; introgression; Phaseolus vulgaris

\section{Introduction}

Common bean (Phaseolus vulgaris L.) is a key grain legume crop and a vital source of nutrition worldwide. The FAO reports that half of the world's common bean production occurs in low income, food deficit countries where this staple crop contributes to food security. The other half is produced in countries like the U.S., where common bean is an important economic crop with 769 thousand hectares of dry and snap beans planted in 2012, and with a farm gate value of $\$ 1.5$ billion [1]. The value of the common bean crop exceeds that of all other legumes combined, including chickpea, lentil, pea, and cowpea, thus indicating the current and potential future economic role of this crop. Abiotic and biotic constraints to common bean production result in average global yields $<600 \mathrm{~kg} \mathrm{ha}^{-1}$, while yields in the U.S. and Canada are about three times as high. This yield gap results in food insecurity, and thus the need for novel sources or combinations of traits in common bean to increase potential productivity or reduce losses in low-input agriculture. To keep up with population growth, a 30\% increase in common bean yield is needed by 2050, while increasing temperatures are predicted to gradually limit the regions and/or seasons favorable for common bean production in most countries [2]. Among the climate change-associated constraints, high temperature and drought stress are likely to have the greatest effect on common bean productivity, while associated changes in the disease complex are also of concern. In order to confront these constraints, novel genetic variants need to be identified and utilized by bean-breeding programs. The narrow genetic diversity present in most market classes of beans limits current breeding efforts, while crop wild relatives (CWR) and closely related species are a largely untapped source of novel genetic variation that needs to be further explored.

Common bean yield improvement has focused on genetic diversity present in the relatively narrow gene pool of improved cultivars and landraces, while wild germplasm and closely related species have been underutilized, being used effectively on single gene traits related to resistance to disease, e.g., common bacterial blight, caused by Xanthomonas axonopodis pv. phaseoli, and pests such as bruchids. Although the use of wild relatives has been successful in increasing yield in common bean [3], their use for the improvement of other quantitative traits has been limited. The restricted use of wild relatives is partly due to the lack of knowledge about the phenotypic or genotypic components of abiotic stress tolerance, the difficulty in introgression from wide crosses, and the lack of effective phenotyping platforms. In addition to wild relatives of common bean, closely related species can be employed for common bean improvement, including: $P$. acutifolius $P$. coccineus $P$. costaricensis and $P$. dumosus.

A meeting was organized by the Global Crop Diversity Trust (GCDT) from 28-30 March 2012 at the International Center for Tropical Agriculture (CIAT) in Cali, Colombia for the purpose of assembling recommendations for the use of wild relatives for improving drought and heat tolerance, and associated 
biotic stress, in common bean. The approach of the meeting was to bring a diverse group of scientists together for consultation and produce a convergence of ideas based on cutting edge research in taxonomy, genetic resources, applied plant breeding, and genomics. Participants at the meeting represented international institutions, including: Global Crop Diversity Trust, Italy; INIFAP, UNAM, CINVESTAV, Mexico; CIAT, Colombia; U. of Guelph, U. of Saskatchewan, Canada; and the U. of Puerto Rico, U. of Georgia, Michigan State U., U. of Idaho, Agriculture Research Service (USDA), U. of Nebraska, and U. of California-Davis, all located in the U.S. An important objective of the meeting was to determine how wild relatives and closely related species of cultivated Phaseolus species might be used for the introgression of unique sources of drought and heat tolerance with the potential to significantly increase yield potential under expected climate change scenarios.

\section{Results and Discussion}

This review provides a rationale for proposed research and considers common bean response to climate change, Phaseolus species resources and conservation, the current use of wild relatives and closely related species in breeding efforts, and available genomic tools. The proposed research strategies and knowledge gaps are then presented based on the suggestions of the assembled group of scientists at the meeting.

\subsection{Climate Change}

Current climate change estimates predict global temperature increases of between 1.4 and $3{ }^{\circ} \mathrm{C}$ by 2050 and region-specific increases or decreases in precipitation [4,5], resulting in changes in agro-ecological zones and in the disruption in crop production systems. These dramatic climatic change scenarios over the short-term result in sobering predictions of yield reduction in crops, especially in abiotic-stress-sensitive crops such as common bean. Interactions of a changing environment with other associated constraints, such as low soil fertility, root health, waterlogging and emerging diseases or pests must also be considered in the developing country context. Because drought has the potential to affect about two-thirds of common bean production areas, improvements in heat tolerance and drought tolerance could increase areas suitable for common bean production by $54 \%$ and $31 \%$, respectively [6]. Plant-breeding efforts have resulted in a modest, but steady increase in seed yield of approximately $0.7 \%$ per year in common bean in the U.S. [7]. These yield increases need to be considered in light of a global warming increase of $1{ }^{\circ} \mathrm{C}$ during the last century. Although some improvement in abiotic stress tolerance has been achieved, it is unclear if the rate of breeding progress is sufficient to offset the effects of future climate change and the marginalization of common bean production areas due to competition with more heat and drought-tolerant crops, such as cowpea. In some agro-ecological zones where future abiotic stress conditions are expected to be excessively severe for common bean production, the use of closely related species, including Lima bean (Phaseolus lunatus L.) and tepary bean (Phaseolus acutifolius L.) can be expanded. This is already the case in some regions such as the semi-arid northeast of Brazil where the Lima bean is an important crop, and the hot Pacific coast of Central America and the arid and semi-arid lands (ASALs) of Kenya [8] where tepary bean is produced. These under-utilized and orphan crops would benefit from selection for improved agronomic traits and resistance to key diseases or pests to achieve significant yield, quality, and agronomic gains, as well as adaptation for production in a wider 
range of environments. Both tepary and Lima bean may be suitable for production in parts of tropical America, the Caribbean and Africa, whereas the heat and drought-tolerant tepary bean may have more potential in the Middle East, and the Lima bean in South Asia. Thus, these albeit novel and somewhat risky but potentially game-changing approaches and strategies must be considered to achieve the necessary yield gains to feed the world population under changing environmental conditions.

\subsection{Genetic Resources and Conservation}

The bean in your garden is about the same as the viney legume wild relative growing in the understory of montane forests in Mexico, Central America and the Andean region. It is considered only "about the same," since the differences are all related to the traits that you and other bean gardeners have been selecting for centuries, or even millennia: pods that do not open at maturity (so you do not have to look for your seed in the ground cover), larger seeds (and thus larger pods, so fewer of them fill your plate, and less work to harvest them), perhaps a bush growth habit (if you desire an early crop or monocropping). These traits belong to the domestication syndrome, and are controlled by a few genes with large phenotypic effects $[9,10]$. However, all the other morphological and physiological traits in your garden bean are the same as in its wild ancestor. The presence of a wild ancestor suggests such questions as: When did the ancestor appear? Is it alone? Where is it distributed? What are the reasons behind this distribution? What can it offer for the breeding of the crop?

How can we be sure a plant is a wild ancestor and not a weedy fugitive from cultivation, as happens in other crops such as beet (Beta vulgaris), oat (Avena sativa), and sorghum (Sorghum bicolor)? Two groups of evidence support the wild ancestor concept for common bean. First, Phaseolus vulgaris L. does not survive long after cultivation, even under favorable conditions. For example, common bean is grown in California and in Ethiopia, yet feral forms are unknown in these respective native floras $[11,12]$. Second, the higher number of molecular polymorphisms and their rate of mutation and inheritance (for seed storage proteins [13,14]; for RFLPs of mitochondrial and genomic DNA [15,16] respectively; for five sequenced gene fragments [17]) existing in the wild forms as compared to the cultivated ones indicate that the latter originate from the former, and not the reverse.

Three points make the common bean wild ancestor worth studying. First, it is currently alive and as an annual liana, it blooms and disperses seed in open montane forests from Mexico to Argentina (Figure 1). The range known today extends from Chihuahua [18] in the North, to Cordoba [19] in the South. Because of its ecological requirements for moderate temperatures and a long dry season, wild common bean will thrive at altitudes where rainfalls coincide with favorable temperatures (summer). That is why wild P. vulgaris is absent from the Mediterranean climates of the Americas (e.g., California [11]; Chile [20]). The altitude range of wild beans extends from $700 \mathrm{~m}$ in Tucumán, Argentina to 2,900 $\mathrm{m}$ in Cuzco, Peru [21], while the orography of the Americas fragment the habitat of wild P. vulgaris into blocks separated by geological discontinuities at lower altitudes, such as: the Isthmus of Tehuantepec, Lake Nicaragua, the Isthmus of Panamá, and the Salinas Grandes of Catamarca (Argentina). There are thus groups of populations of wild common bean in Sierra Madre Occidental, (western) part of the Neo-Volcanic Axis, and Sierra Madre del Sur in Mexico, and a distribution towards the Pacific slope in Central America. There is an outstanding feature in the Andes: while wild P. vulgaris is commonly distributed in inter-Andean valleys towards the eastern slope [22], in Ecuador and 
northwestern Peru, it is distributed towards the western slope [23]. Moreover, in the Andes, the ecological niche of wild $P$. vulgaris is much narrower in longitude as compared to Mesoamerica.

Figure 1. A wild P. vulgaris population (\#1715) on an open sunny slope of arroyo Santa Victoria, Salta, Argentina, with its ripe golden pods, sampled in April 1986.

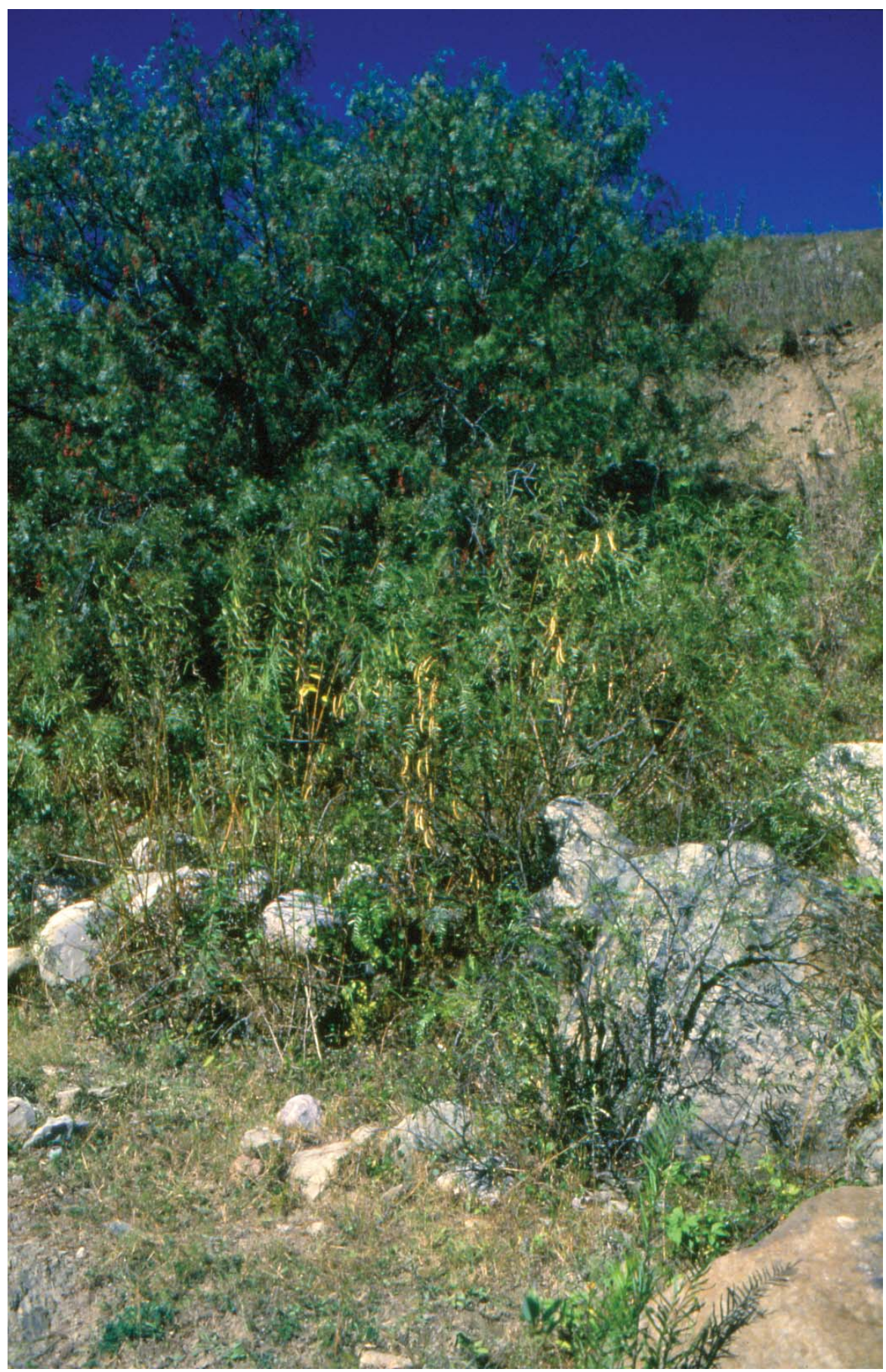

Second, the fragmented distribution of wild common bean is reflected in its genetic makeup (e.g., phaseolins: [24-27]). These genetic differences displayed at the molecular level mean that they are ancient, and can be explained by past trans-isthmic migrations during the Tertiary period [28]. A first migration from Mesoamerica into the Andes allowed future populations to be domesticated in the central Andes (with the "C" haplotype [29]). It also provided for the foundation of the Pacific clade, today 
distributed in southern Ecuador and NW Peru [23], with "I" phaseolin [25], once recognized as ancestral [30]. In a second migration, this Pacific clade would have extended back into Costa Rica where the "H" haplotype is found today [28] — and not in the cultivated beans of Costa Rica. In the meantime, the original wild stock of $P$. vulgaris differentiated further by exploiting a wider longitude gradient, producing up to six haplotypes [28], four of which were found in the cultivated varieties of Mesoamerica [29]). It produced a third clade, the expansion of which ends up today in the Colombian eastern highlands [28], as an indication of the third trans-isthmic migration, made possible thanks to past climatic oscillations [31].

Third, these genetic differences are also reflected in protein, enzyme, secondary metabolite, and physiological differences. For instance, arcelins - a special group of seed proteins stored in the cotyledons [32] — seem restricted to wild beans from Mexico [33], and those with insecticidal properties specifically to western Mexico [34]. Contrary to expectations, the presence of arcelin variants that cause antibiosis in bruchids does not confer an advantage in natural selection-since all wild populations along the entire range would have the trait if it did — but rather reflects the natural variation existing in the species. On the other hand, natural variation also exists for photosynthetic nitrogen use efficiency with high values in wild forms from Mexico [35], and carbon dioxide exchange rates with lower values for Peruvian landraces as compared to their wild counterparts [36]. Wild forms can also contribute QTLs (quantitative trait loci) for yield in different genetic backgrounds [9,37], and this approach has been found valuable in tomato [38] and rice [39] breeding as well.

The understanding that common bean has a living wild ancestor was realized relatively late, in the 1960s [40-42]. In addition, the discovery that it could have been domesticated twice and independently [43,44], from different populations in Mesoamerica and the Andes, has also been recent. This double domestication has been widely established by Chacón et al. [29], Gepts et al. [24] and Kwak et al. [45]. But the understanding that common bean has sister species in the genus is even more recent. Maréchal et al. [46] showed that $P$. coccineus L. and some of its wild relatives, and $P$. dumosus Macfady. (syn. P. polyanthus Greenm.) shared genetic affinity with common bean. Schmit et al. [47] indicated that $P$. costaricensis Freytag and Debouck should be added to that list, as should P. albescens McVaugh ex Ramírez and Delgado in a later work [48]. Additional material should be studied for $P$. persistentus Freytag and Debouck which could indicate that it is part of the same common bean lineage [49]. Thus, the section Phaseoli [50] could have six taxa as wild species to date (Table 1): $P$. albescens $P$. coccineus $P$. costaricensis $P$. dumosus $P$. persistentus and $P$. vulgaris. Based on current evidence, it should be noted that for the Phaseoli section, only P. vulgaris exists as a wild in South America. However, P. dumosus - a wild in western Guatemala — can be a weed in the northern Andes [51], as well as some P. coccineus escapes in the Colombian and Ecuadorian Andes [52]. Wild P. coccineus is known from Chihuahua, Mexico, South to Jalapa, Guatemala [18,53]. P. costaricensis (Figure 2) has its natural distribution in the mountains of eastern Costa Rica and western Panamá [54,55]. P. albescens is a vine in the montane forests of western Mexico [56]. It would thus not be impossible that the section Phaseoli has undergone most or the totality of its speciation process in Central America. Recent evidence also points to a Mesoamerican origin for P. vulgaris itself [17]. 
Table 1. Sections and species currently recognized in the genus (partly based on Delgado-Salinas et al., 2006 [49]; Freytag and Debouck $2002[50])$.

\begin{tabular}{|c|c|c|}
\hline Sections & Species & Total \\
\hline Clade A (8 sections) & 38 species (4 widespread; 11 with intermediate range; 23 endemic) & \\
\hline \multicolumn{2}{|c|}{ Not assigned to any section, nor forming any section with each other: glabellus, microcarpus } & 2 \\
\hline Bracteati Freytag & macrolepis, talamancensis & 2 \\
\hline Brevilegumeni Freytag & campanulatus, hygrophilus, oligospermus, tuerckheimii & 4 \\
\hline Chiapasana Delgado & chiapasanus & 1 \\
\hline Digitati Freytag & albiflorus, albiviolaceus, altimontanus, neglectus & 4 \\
\hline Minkelersia (Mart. \& Gal.) & \multirow{2}{*}{ amabilis, amblyosepalus, anisophyllus, nelsonii, parvulus, pauciflorus, plagiocylix, pluriflorus, tenellus } & \multirow{2}{*}{9} \\
\hline Maréchal,Mascherpa,Stainier & & \\
\hline Pedicellati (Benth.) Freytag & dasycarpus, esperanzae, grayanus, laxiflorus, oaxacanus, pedicellatus, polymorphus, purpusii, texensis & 9 \\
\hline Revoluti Freytag & leptophyllus & 1 \\
\hline Xanthotricha Delgado & esquincensis, gladiolatus, hintonii, magnilobatus, xanthotrichus, zimapanensis & 6 \\
\hline Clade B (6 sections) & 39 species ( 12 widespread; 7 with intermediate range; 20 endemic) & \\
\hline Acutifolii Freytag & acutifolius, parvifolius & 2 \\
\hline Coriacei Freytag & maculatus, novoleonensis, reticulatus, ritensis, venosus & 5 \\
\hline Falcati Freytag & leptostachyus, macvanghii, micranthus & 3 \\
\hline Paniculati Freytag & $\begin{array}{l}\text { albinervus, angusti, jaliscanus, juquilensis, lignosus, lunatus, maculatifolius, } \\
\text { marechalii, mollis, nodosus, pachyrrhizoides, polystachys, rotundatus, salicifolius, } \\
\text { scrobiculatifolius, sinuatus, smilacifolius, sonorensis, viridis, xolocotzii }\end{array}$ & 20 \\
\hline Phaseoli DC & albescens coccineus costaricensis dumosus persistentus vulgaris & 6 \\
\hline Rugosi Freytag & angustissimus, carterae, filiformis & 3 \\
\hline & Total (no. sections): 14. Total (no. species): 77 & \\
\hline
\end{tabular}


Figure 2. A population of $P$. costaricensis (\#3246) found in the buffer zone of Chirripó national park in San José province of Costa Rica in December 2012.

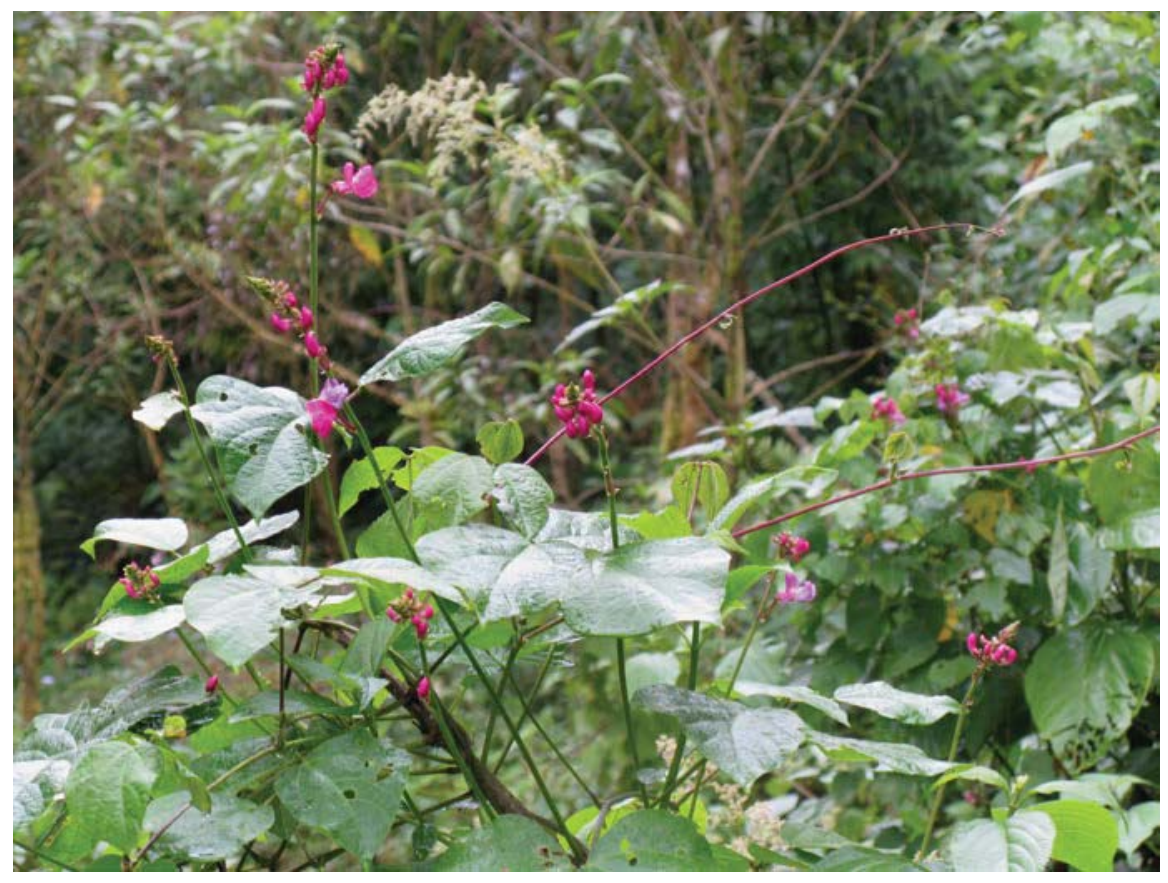

A time perspective can perhaps explain part of the above features. The genus Phaseolus under its current sensu stricto understanding, excluding the other Neotropical-related legumes [46,57,58], would have an age of 8 to 5 million years [57,59]. Its major clades, A and B with approximately 38-40 species each (Table 1), would have separated about 5 million years before present (B.P.) [49]. The common bean as a species has been estimated to have an age of 3.9-1.8 million years B.P. [49], 2 million years B.P. [60], or 1.3 million years B.P. [28] when it separates from its sister taxa P. albescens, P. dumosus, and $P$. costaricensis. The age of the gene pools within $P$. vulgaris, namely the time which the Pacific clade was formed, would be 600,000 years B.P. [28] or 500,000 years B.P. [60]. "With reference to the Panama land bridge, it is noteworthy that following completion at $\sim 3.5$ million years ago, the landscape was low-lying and could accommodate tropical migrants, while those requiring more temperate conditions would find a few, widely scattered highlands available only after $\sim 2.5$ million years ago" ([31], p. 479). Of the bean species with colonizing behavior, P. lunatus, the subsequent species to evolve, would have been migrating southwards into South America long before P. vulgaris [61]. The distance in space and time of respective evolution of these two economically important bean species explains their genetic isolation, and why they cannot be intercrossed successfully $[62,63]$.

Although we are still missing paleobotanical and archaeological data about the age of species and gene pools, the comparison of durations of the common bean as cultivated and as wild is interesting. The latest evidence points to a domestication of common bean up to 2000 years B.P. in Mesoamerica and 4000-5000 years B.P. in the central Andes [64-66]. In other words, the crop in your garden is 2000-5000 years old, while its wild ancestor is 3.9-1.3 million years old. From the viewpoint of mere accumulation of potentially interesting traits, the largest stock is likely to be on the wild side, even though the breeder will always prefer the perfect cultivated mutant in the gene pool she/he is breeding! What does not increase your chances of wider genetic diversity either is the fact that few domestication events took place (one to three in Mesoamerica and one in the Andes [29,45]), which means that most of 
the diversity was left untouched in the wild. The reason that most of the wild diversity was not domesticated might lie with the clever early domesticators who were not interested in re-doing the process but rather in exchanging their early successes, but also in the limited technologies to deal with the anti-nutritional factors in seeds of the wild ancestors [67,68].

The above has some bearing in relation to the traits often associated with climate change, namely drought and high temperatures during flowering and early pod setting. To ensure discovery of sources of tolerance, taxa that diverged early on from the Phaseoli to inhabit these difficult environments of Aridoamerica or the surroundings of the Gulf of California [69] should be investigated. P. filiformis Bentham is one such escape. P. filiformis no longer crosses successfully with the common bean [70,71], while it has tolerance to salinity [72] and extreme temperatures [73]. Another early (2.5 million years ago [49]), apparent escape from the Phaseoli section is the tepary bean, P. acutifolius, with which the common bean can still cross with difficulty [74], and with proven tolerance to high temperature [75], drought [76] and salinity [72]. In the meantime, the Phaseoli have colonized the montane forests of Mesoamerica, turning into tall (six meters and higher) pluriannual lianas, with fibrous root systems, epigeal germination, multiflowered racemes with showy flowers with spreading wings and active nectaries at the floral disk [50]. The montane forests with some continuity of rains and mist, even during the dry season, allow the long stems to not dry up completely and to re-sprout when the rains return. The morpho-physiological exception is $P$. coccineus, which has hypogeal germination and tuberous roots, and the ecological exception is somehow $P$. vulgaris itself because it left the forest habitat to become an annual therophyte in trees, including Quercus-Acacia in Mexico-Guatemala, Alnus-Celtis in South America [41,77], respectively, and grasslands. Wild common bean usually evades drought as pod filling coincides with the end of the summer rains ([41], personal observations across the range). The plasticity of wild $P$. coccineus, with some populations colonizing xeric environments in Chihuahua, Sonora, Durango and Zacatecas, Mexico [18,50], should be mentioned too. In conclusion, the original ecology of the Phaseoli would not make them primary sources of tolerance to high temperature, drought and salinity, but rather the desert native Acutifolii, where the tepary bean can be improved through breeding. That said, the Phaseoli might be good sources of resistance to biotic stress, such as fungal diseases (e.g., white mold: [78]), if excessive rains come with climate change.

In view of future evaluation, a baseline is needed for the number of populations of the Phaseoli that may exist and how many of them are represented in genebank collections (Table 2). The number of known populations living free in nature (although some might now be extinct) is given by the number of vouchers in herbaria or seed accessions, because both represent a bean population growing at a particular locality that can be georeferenced. Voucher specimens can be seen in "Cahiers de phaséologie" [22], a compilation from 80 institutions visited to date. In counting through and re-checking the coordinates, a population is counted once although it might have been sampled by several botanists at different times. For calculating the possible number of populations, the life zones and vegetation types appropriate for the taxon is considered that would be worth sampling. The percentage gap measured is an estimate of the gap in representation in genebanks, in this case that of CIAT. Once variants within accessions have been combined, the total number of populations hypothesized to exist can be estimated. Table 2 complements and updates with new data what has been presented elsewhere [79]. About P. vulgaris, one should note that in several cases collectors (e.g., Howard Scott Gentry, Salvador Miranda-Colín, and Oliver Norvell) collected seed for germplasm conservation, but not herbarium vouchers. As an additional indication, 
when references are available, an estimate is given for the populations known to be included in a protected area (e.g., national park, Biosphere reserve). The numbers look low, and surely because few protected areas have full inventories of plants within their borders, perhaps because wild relatives of crops (with the outstanding exception of Manantlán in Jalisco, Mexico [80]) are rarely considered for protection in situ! One can further note that the numbers of populations are finite, likely because the acreage of the life zone in which these wild species are thriving is fixed under the present geological/edaphic and climatic contexts. Finally, the sharp contrast between the numbers of populations of wild $P$. coccineus and $P$. vulgaris and the other wild Phaseoli is likely not by chance, but rather reflects the capacity of the former taxa to colonize habitats, even those modified by humans. The former taxa were considered widespread in Table 1, but in contrast to another widespread species such as P. microcarpus Mart., they did respond positively to human selection. Agriculture is first of all an ecological disturbance!

Table 2. Current conservation status for the Phaseoli section (in September 2012).

\begin{tabular}{|c|c|c|c|c|c|}
\hline $\begin{array}{c}\text { Species (wild), } \\
\text { country }\end{array}$ & $\begin{array}{c}\text { Known } \\
\text { populations }\end{array}$ & $\begin{array}{c}\text { Possible No. of } \\
\text { populations }\end{array}$ & $\begin{array}{l}\text { Accessions in } \\
\text { genebanks }\end{array}$ & Gap as \% & $\begin{array}{l}\text { Populations in } \\
\text { protected areas }\end{array}$ \\
\hline \multicolumn{6}{|c|}{ P. albescens } \\
\hline Mexico & 13 & 18 & 1 & 85 & 2 \\
\hline \multicolumn{6}{|c|}{ P. coccineus } \\
\hline Mexico & 342 & 462 & 106 & 77 & 12 \\
\hline Guatemala & 64 & 66 & 59 & 10 & 4 \\
\hline Honduras & 4 & 12 & 3 & 50 & 0 \\
\hline \multicolumn{6}{|c|}{ P. costaricensis } \\
\hline Costa Rica & 47 & 49 & 8 & 83 & 2 \\
\hline Panama & 10 & 12 & 0 & 100 & 2 \\
\hline \multicolumn{6}{|c|}{ P. dumosus } \\
\hline Guatemala & 11 & 19 & 9 & 53 & 2 \\
\hline Mexico & 1 & 1 & 0 & 100 & 0 \\
\hline \multicolumn{6}{|c|}{ P. persistentus } \\
\hline Guatemala & 1 & 2 & 0 & 100 & 0 \\
\hline \multicolumn{6}{|c|}{ P. vulgaris } \\
\hline Mexico & 110 & 420 & 395 & 6 & 6 \\
\hline Guatemala & 16 & 45 & 39 & 14 & 3 \\
\hline Honduras & 5 & 18 & 6 & 65 & 0 \\
\hline El Salvador & 2 & 4 & 1 & 50 & 1 \\
\hline Nicaragua & 7 & 8 & 4 & 50 & 0 \\
\hline Costa Rica & 24 & 25 & 30 & 1 & 1 \\
\hline Panama & 0 & 2 & 0 & 100 & 0 \\
\hline Colombia & 74 & 79 & 74 & 6 & 0 \\
\hline Venezuela & 2 & 18 & 0 & 100 & 0 \\
\hline Ecuador & 10 & 12 & 10 & 4 & 1 \\
\hline Peru & 32 & 38 & 31 & 12 & 2 \\
\hline Bolivia & 11 & 14 & 11 & 4 & 0 \\
\hline Argentina & 87 & 96 & 66 & 31 & 4 \\
\hline
\end{tabular}




\subsection{Use of Wild Relatives and Closely Related Species in Common Bean Breeding}

Tanksley and McCouch [81] noted that domestication resulted in a significant loss of genetic variability for most crops. The common bean is no exception where less genetic variability exists among cultigens than wild beans [29], especially for bean cultivars in the Andean gene pool [82]. Additional support for the lack of variation in both the wild and cultivated Andean gene pools comes from sequence information on 214 (102 wild, 112 domesticated) accessions of P. vulgaris [83]. In addition to the expected reduction in genetic variability between wild and cultivated members of both gene pools, a threefold greater reduction was observed in the Middle American than in the Andean gene pool [83]. The authors explain this anomaly as a bottleneck that occurred prior to domestication that improvised the wild Andean gene pool. In an earlier paper, Bitocchi et al. [17] suggest that both the wild and cultivated Andean gene pool originated, not as previously thought in the Andean region, but in the Middle American region of central Mexico. Limited migration from Middle America would explain the lower levels of genetic variation among members of the wild Andean gene pool. Wild common beans (primary gene pool) represent an almost unexploited source of potentially valuable traits for the improvement of common bean [3]. Gepts and Debouck [84] noted that wild beans grow in Mexico, Central and South America in a wide range of altitudes, soil types and rainfall distribution patterns. Wild beans are also exposed to endemic populations of pests and pathogens which are often highly virulent to domesticated bean cultivars [85]. Acevedo et al. [86] suggested that monitoring of plant pathogen populations such as rust (caused by Uromyces appendiculatus) on wild beans in native habitats provides opportunities to monitor virulence patterns of pathogens and develop strategies to deploy resistance genes.

Wild and domesticated beans can be readily crossed, although Blair et al. [9] noted that differences in patterns of flowering and growth cycle may complicate the task of synchronizing flowering. Keneni et al. [87] pointed out that wild species generally have poor agronomic performance and that breeding for traits such as disease or pest resistance may be difficult if the mechanism of resistance affects productivity or crop quality. Although wild beans tend to be viney, indeterminate plants with small seed, plant breeders at CIAT have been able to recover acceptable seed size and agronomic traits using the inbred backcross breeding method [3].

Wild beans have already been used as sources of resistance to economically important diseases and pests. The previously mentioned seed protein arcelin, which confers moderate levels of resistance to bruchids (Acanthoscelides obtectus and Zabotes subfasciatus), was originally identified in wild bean accessions from Mexico [88]. Crosses with wild bean accessions were used to develop common bean germplasm possessing different alleles of arcelin and varying levels of resistance to bruchids [89]. Kornegay et al. [90] demonstrated that the different forms of arcelin are inherited as a single dominant gene. Backcrossing has been employed at CIAT to incorporate Arc-1 into RAZ breeding lines that have good levels of resistance to Zabrotes subfasciatus. Despite the awareness of this source of resistance for more than two decades and the severity of losses caused by bruchids, there have been, to date, no formal releases of bean cultivars with resistance to this pest.

Beaver et al. [91] released a web blight [caused by Thanatephorus cucumeris (Frank) Donk] and common bacterial blight (caused by Xanthomonas axonopodis pv. phaseoli)-resistant black bean germplasm line PR0650-31 that was derived from the cross BAT 93/PI 417662//VAX 6. PI 417662 is a wild type bean germplasm that was collected in Jalisco, Mexico (USDA-ARS, NGRP, 2009). It was part 
of a core germplasm collection of wild and domesticated $P$. vulgaris that was screened in Puerto Rico for resistance to web blight. Acevedo et al. [92] identified two wild bean accessions from Honduras with high levels of resistance to rust that could be used to broaden the base of resistance to this important disease. Mkwaila et al. [93] reported QTLs for white mold (caused by Sclerotinia sclerotiorum) resistance in an inbred backcross line population derived from a cross between the black bean cultivar 'Tacana' as the recurrent parent and the Mexican wild bean accession PI 318695.

Less progress has been made using wild beans for quantitatively inherited traits such as tolerance to abiotic stress or seed yield. Acosta-Gallegos et al. [3] reported the development of an inbred backcross population from a cross between $\mathrm{G}$ 24423, a wild bean accession from Colombia, and the Mexican black bean cultivar 'Negro Tacana'. One $\mathrm{Bc}_{2} \mathrm{~F}_{4: 7}$ line from this population, $115 \mathrm{M}$, produced a mean seed $>5000 \mathrm{~kg} /$ ha in field trials conducted in Michigan [94]. A recombinant inbred line (RIL) population was developed at Michigan State University from a cross between $115 \mathrm{M}$ and the black bean cultivar 'Jaguar'. The RILs were tested in replicated yield trials in Michigan over a four-year period. Wright and Kelly [95] reported the identification of a major QTL for seed yield in this population that was mapped on linkage group Pv10.

Blair et al. [9] conducted a QTL analysis of seed yield using advanced backcross lines from a cross between the large red-seeded cultivar 'ICA Cerinza,' of Andean origin, and a wild bean accession, G24404. Based on results from field trials conducted in Colombia, several QTLs for seed yield and seed yield components were identified, including a QTL for larger seed size from the wild bean. The authors point out the need to develop appropriate breeding methods to exploit genetic variability of wild beans.

The common bean can also be crossed with the scarlet runner bean (Phaseolus coccineus L.) which represents a secondary gene pool. Differences in photoperiod sensitivity, flowering pattern and other factors, identified by Blair et al. [9], as barriers for crossing wild beans also apply for interspecific crosses between common bean and scarlet runner bean. Ferwerda and Bassett [96] identified three incompatibility barriers in crosses between common beans and scarlet runner beans; blocked cotyledon lethal, crinkle leaf dwarf and dwarf lethal that are controlled by complementary dominant gene action. They reported that the black bean line 5-593 and the snap bean cultivar 'Regalfin' could serve as useful bridging lines to transfer desirable traits from scarlet runner beans to common beans. The black bean cultivar 'ICA Pijao,' which does not have the dominant $D l$ genes [97], has been used at CIAT as a parent in crosses with scarlet runner beans.

Scarlet runner beans are often found in cloud forests of Central America and Mexico where climatic conditions are favorable for the development of fungal diseases such as rust, anthracnose (caused by Colletotrichum lindemuthianum) and web blight. Moreover, wild populations of common bean and scarlet runner beans are often found growing together. As a consequence, scarlet runner beans in their native habitat are exposed to endemic populations of common bean pathogens which can be highly virulent [85,98]. There are numerous examples of the development of disease-resistant common bean germplasm and cultivars from interspecific crosses between common bean and scarlet runner bean.

Singh et al. [99] reported that the scarlet runner bean accessions G35172 and G35005 had resistance to multiple diseases of common bean including bean golden yellow mosaic virus (BGYMV) and white mold. Singh et al. [99] reported the release of white mold-resistant VCW 54 and VCW 55 bean germplasm lines that were developed using congruity backcrossing between the black bean cultivar ICA Pijao and the scarlet runner bean accession G35172. Osorno et al. [100] found G35172 to have a 
recessive gene, $b g m-2$, that conferred resistance to leaf chlorosis and a dominant gene, Bgp-2, that conferred resistance to pod deformation caused by BGYMV.

Schwartz et al. [101] studied the inheritance to white mold resistance in two populations derived from interspecific crosses between common bean and scarlet runner bean. Their results suggested that the white mold resistance of the scarlet runner bean accessions PI 433246 and PI 439534 were controlled by a single dominant gene. Two interspecific bean lines originally screened in Puerto Rico for resistance web blight and subsequently screened in Idaho for white mold resistance had among the highest levels of resistance to white mold in straw tests conducted in seven different university laboratories in the U.S. [102].

Wilkinson [103] reported that the root rot resistant line Cornell 2114-12 was derived from a cross between common bean and scarlet runner bean lines. Miklas et al. [104] developed and released the common bacterial blight resistant bean germplasm lines ICB-3, IBC-6, ICB-8 and ICB-10 which were derived from an interspecific cross with scarlet runner bean. Schmit and Baudoin [105] identified accessions of $P$. coccineus and $P$. dumosus (syn. P. polyanthus) that had high levels of resistance to Ascochyta blight in Colombia.

Mahuku et al. [106] reported that $P$. dumosus expressed a higher level of resistance to anthracnose in Colombia than $P$. coccineus. This higher level of resistance was also reflected in lines derived from crosses between scarlet runner bean and common bean.

Freytag et al. [107] released the common bacterial blight-resistant germplasm line XR-235-1-1, which was derived from an interspecific cross between common bean and scarlet runner bean. Zapata et al. [108] also released common bacterial blight bean germplasm lines W-BB-11, W-BB-20-1, W-BB-35, W-BB-52, and W-BB-56 from interspecific crosses with scarlet runner bean. WBB-20-1 was used as a parent in the development of the common blight resistant cultivar 'Verano' [109].

Accessing traits from members of the primary and secondary gene pools of Phaseolus has been relatively routine, requiring no special techniques other than matching flowering times, and the choice of species used as the female parent in crosses with $P$. coccineus. The $P$. vulgaris $\times P$. coccineus hybrid occurs naturally and can be easily made by controlled pollinations whereas reciprocal crosses have met with limited success due to unidirectional compatibility, postzygotic barriers and $\mathrm{F}_{1}$ hybrid sterility [110]. Crosses with wild accessions of $P$. vulgaris have been equally routine even across gene pools. The $D l$ incompatibility alleles that arise in inter-gene pool crosses of cultivated $P$. vulgaris are also present in wild members. The $D l$ genes appear to have arisen before domestication as a consequence of geographic isolation, rather than as a consequence of selection pressure to eliminate unadapted hybrids among cultivars [111].

Scarlet runner beans have been used less by plant breeders to improve tolerance to abiotic stress. Plant breeders at CIAT, however, are currently using interspecific crosses with scarlet runner beans to improve the aluminum tolerance of common bean [112]. Given the adaptation of scarlet runner beans to higher altitudes and the viney growth habit of most accessions, the scarlet runner bean may be of particular value to the improvement of climbing beans.

Hybridization between common bean and tepary bean (Phaseolus acutifolius A. Gray), which is a more distant relative of common bean and represents a tertiary gene pool, is difficult. Tepary beans have their origin in warmer and more arid environments than common bean. Some tepary landraces have superior heat [113] and drought tolerance [114-116]. Under favorable growing conditions, adapted 
tepary bean lines are capable of producing seed yields comparable to common beans [76,117]. Crosses between tepary bean in the tertiary gene pool and common bean have been more challenging, requiring the use of embryo rescue to secure viable embryos and breeding methods not commonly deployed in breeding programs. Tepary bean has been recognized as a valuable source of traits for heat and drought tolerance, insect and disease resistance, but early attempts to transfer many of these traits have had limited success due to their genetic complexity and resultant $\mathrm{F}_{1}$ sterility [118]. Ferwerda et al. [119] reported that viable $F_{1}$ seed was easier to obtain when certain tepary accessions such as PI 321638-s are used as parents. A detailed summary of early attempts at species introgression is provided by Pratt [120]. Congruity backcrossing (CBC) was first reported as a method to produce fertile intermediate hybrids between $P$. acutifolius and $P$. vulgaris [121]. The method involves recurrent backcrossing to each parent in alternate generations as opposed to the traditional recurrent backcrossing to a single recurrent parent [121]. The method allows substantial recombination between distant species and new phenotypes can arise as a result of $\mathrm{CBC}$ [122]. The method has been adopted by bean breeding programs as an effective means to force introgression and eliminate barriers such as embryo abortion and hybrid sterility between distant species [123]. CBC has also been used to transfer traits from wild tepary species $P$. parvifolius into common bean [124]. The successful transfer of resistance to common bacterial blight from tepary into common bean has been reported by several authors $[125,126]$.

The bean breeding line XAN 159 has common bacterial blight resistance derived from tepary bean [127]. XAN 159 was used as a parent in the development of the common bacterial blight resistant Great Northern bean cultivar 'ABC Weihing' [128] and pinto bean germplasm line 'ABCP-8' [129]. Marker-assisted selection (with the SU91 SCAR marker) was used in South Africa to introgress CBB resistance from XAN 159 (tepary derived CBB resistance) into speckled sugar and small white beans [130]. Costa et al. [131] reported using tepary bean as a source of CBB resistance for common beans.

Singh and Muñoz [126] used intensive screening for resistance to introgress high levels of resistance to common bacterial blight from tepary bean to the common bean breeding lines VAX 1 to VAX 6. VAX 6 was used as a parent in the development of the common bacterial blight resistant white bean cultivar Verano and VAX 3 was used as a parent in the development of small red cultivar 'Rio Rojo' [132]. It should be noted that the pedigree of Verano includes progenitors that derive CBB resistance from both scarlet runner (WBB-20-1) and tepary bean (VAX 6).

Kusolwa and Myers [133] introgressed seed storage proteins from the APA locus of the wild tepary bean G 40199 into common bean. These common bean breeding lines are resistant to Acanthoscellides obtectus and have been used in Puerto Rico to develop black and white beans that combine resistance to BGYMV, BCMNV and bruchids.

Tepary bean accessions have been identified with several other traits of potential value to common bean breeders including ashy stem blight and Fusarium wilt (F. oxysporum) resistance [134], BGYMV resistance [135] and bean rust resistance [136].

Tepary beans nodulate with Bradyrhizobium spp., whereas common beans nodulate with Rhizobium spp. Therefore, it may be possible to select interspecific lines with more promiscuous nodulation and/or improved biological nitrogen fixation [137].

The successful interspecific hybridization of $P$. vulgaris with members of other wild Phaseolus species has been limited to a few species. Successful interspecific hybrids with $P$. costaricensis in the 
secondary gene pool have been reported [138], and VRW 32 is the first white mold-resistant interspecific breeding line derived from $P$. costaricensis. VRW 32 was derived by recurrent backcrossing of ICA Pijao with wild P. costaricensis germplasm accession G 40604: ICA Pijao//ICA Pijao/G 40604 [139]. Transferring complex traits such as heat and drought tolerance from other species still remains a major hurdle to future improvement of common bean. No successful crosses have been reported between $P$. vulgaris and the Lima bean $P$. lunatus in the quaternary gene pool. However, recent Lima bean research shows broad agronomic, genetic, and cyanogen diversity in a Caribbean germplasm collection [140], which could serve as a source of traits for common bean production in the lowland tropics.

\subsection{Future Breeding and Genomic Strategies for Use of CWR}

The genomics revolution has resulted in the generation of powerful new tools for common bean improvement. The development of a 6000 SNP marker chip for common bean [141], has made genotyping of populations for genetic analysis or breeding lines for marker assisted selection a relatively inexpensive and efficient process. The recent publication of the common bean genome sequence based on the G19833 genotype was completed through a DOE-JGI and USDA-NIFA project [142]. The Version 1.0 of the common bean genome was released in 2012 and is the first chromosome scale sequence of Phaseolus vulgaris, based on 454, RNA-seq, and BAC and fosmid end sequences, and a dense marker map of 7015 markers, resulting in a full, annotated genome. Parallel sequencing projects are currently sequencing germplasm line BAT 93, through a multinational effort (Argentina, Brazil, Mexico, and Spain), and cultivar 'OAC Rex' through an effort in Canada. The creation of these sequence-based resources allows for a new generation of genomics approaches for common bean improvement. As candidate abiotic stress genes are identified from model or crop species, their effects can be directly queried in common bean and diversity investigated in common bean wild relatives. The sequence can also be used for genotype-by-sequence (GBS) and genome wide selection (GWS) approaches.

One of the greatest difficulties preventing the application of CWRs as a routine tool for crop improvement is a lack of knowledge about the genetics of traits of interest in undomesticated, wild germplasm. For example, how does one predict potential contribution to seed yield from undomesticated plants that have small seeds and pods that shatter? Obviously, yield is a complex trait. However, even for simpler traits, say response to heat stress or disease resistance, there can be a disconnection between the genotype and phenotype in CWRs that prevents utilization. The reasons for this disconnect are twofold: (1) a lack of knowledge of the genetic basis of the trait in the CWR; and (2) uncertainty about the behavior of the trait in the genetic background of domesticated bean germplasm. Both questions assume that CWRs are adequately phenotyped such that finding the trait and being able to genetically dissect it would be possible and that sufficient representation of CWRs is available and tested to identify rare genetic variants underlying traits of interest.

A two-pronged approach is proposed to uncover CWR genetic variation. First, high resolution genotyping, e.g., via resequencing, coupled with careful genotyping should lead to the elucidation of the genetic basis of target traits in wild germplasm, thereby allowing one to move those traits into cultivated germplasm in a targeted manner. Thus, this would allow for the creation of genotype-phenotype 
associations in wild germplasm through methods such as association mapping. The effectiveness of this approach with polygenic, quantitative traits is questionable, as is the performance of the genes once moved into domesticated germplasm. A second approach, and perhaps less informed, would be to create populations between CWRs and adapted germplasm to be able to test CWR chromosomal segments for effects on target traits. In combination with genotyping by sequencing, one would expect to uncover genes/chromosomal segments that confer desirable effects on traits of interest.

Genetic information for many of these abiotic traits is lacking in cultivated types, and little to no information is available for wild relatives. Initial genetic analysis in cultivated common bean types will shed light on important genomic regions for further investigation. Thus, QTL and AM (association mapping) analysis for drought and heat in cultivated common bean will be used to identify key regions in common bean before exploring wilds. A secondary genetic analysis will involve a candidate gene approach of genes from Arabidopsis or other model/related species in order to identify allele variants in wild species to transfer into common bean through crossing/transformation. Advances in genomic analysis will allow for whole genome sequencing of larger sets of germplasm and thus the investigation of the whole genome, specific genes, or biosynthetic pathways, while genome sequence and marker information will facilitate the development of NILs for the evaluation of the effects of specific regions/QTL from the wild relative.

Due to the continuing decline in sequencing costs and the relatively small genome size of Phaseolus ( $\sim 650 \mathrm{Mbp}$ ), Phaseolus is uniquely poised to take advantage of next generation sequencing approaches to enhance the utilization of CWRs for plant improvement. Currently on an Illumina HiSeq 2500 platform, it is possible to obtain $\sim 60$ Phaseolus genomes at $1 \times$ coverage per lane. Of course, greater coverage achieved either through deeper sequencing or some type of reduced representation approach would be desired. However, for a few thousand dollars (USD), it is possible to achieve very high resolution sequencing of dozens of accessions at a time, which will subsequently enable the approaches described previously.

The type of genetic/genomic information needed will drive the type and cost of sequencing. For determining SNP variation, there have been reports of both deep sequencing and low level coverage sequencing (discussed in [143]) that have been informative for finding SNPs and for performing genetic mapping [144]. Other types of variation such as presence/absence, copy number, repetitive DNAs and even epigenetic variation will require different types of sequencing. To detect structural variation, large-insert clone libraries to capture breakpoints effectively have to be used and will increase the cost and lower throughput [145]. Sequencing to capture methylated cytosines, a type of epigenetic variation, require specialized libraries and much deeper sequencing as both DNA strands have to be sampled to capture asymmetric methylation [146]. A question that needs to be addressed before embarking on such experiments in Phaseolus, or any species for that matter, is how much of the non-SNP-based variation can be captured with SNP allelic variation? That is, do SNPs in linkage disequilibrium capture genetic variation that is not based on change in DNA sequence? If so, then relatively inexpensive SNP markers can be used to explore, characterize and utilize these types of genetic variation.

In terms of use of wild germplasm for improving common bean through breeding, two general approaches are envisioned (Figure 3). The primary approach will involve the use of a set of 30 selected wild genotypes of common bean or sister species for introgression of abiotic stress tolerance into common bean. The second approach will be a concurrent effort using already available common bean 
germplasm/populations developed from previously developed crosses with wild relatives and sister species. This dual approach provides both higher risk and lower risk approaches that in turn could result in corresponding gains in improvement over a relatively short time frame of ten years.

Figure 3. Approaches for introgression of exotic heat and drought-related traits from wild relatives of common bean.

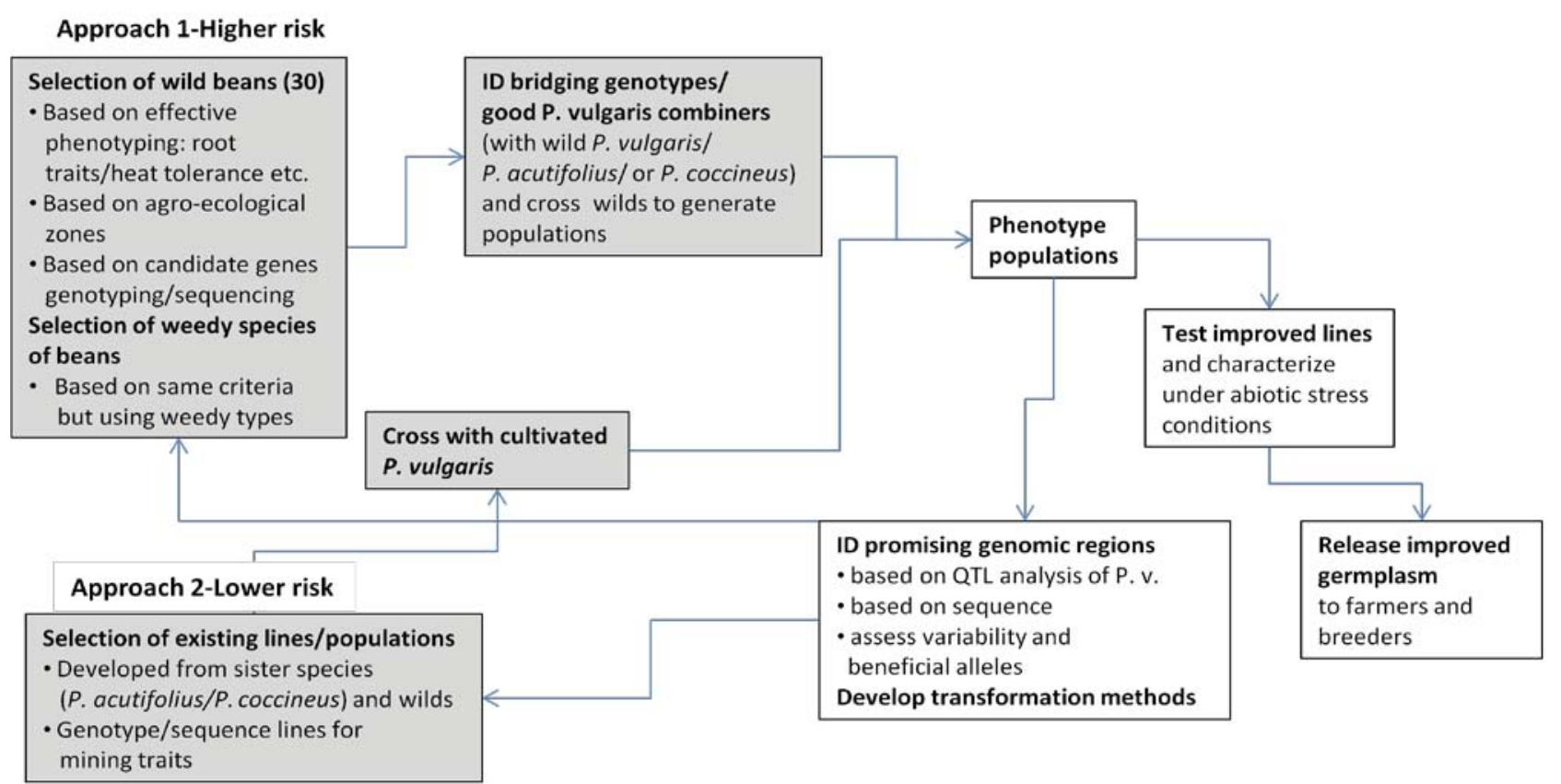

The first approach is higher risk and involves direct use of wild relatives. Due to the phenotypically distinct nature of wild relatives, the challenge of evaluation for abiotic stress tolerance is significant. Traits that contribute to survivability and fitness in the wild may differ from traits that contribute to improved biotic and abiotic stress tolerance. For example, a viney growth habit that permits a bean plant to flower over a longer period of time is a valid strategy in the wild to avoid short periods of drought. This would be an undesirable combination of traits for beans produced in most cropping systems. Instead of basing phenotypic analyses on yield components, as is commonly done for breeding cultivars, putatively correlated traits, such as stomatal and abscission response under stress, and related root traits, need to be investigated. In addition, traits that permit plants to recover from periods of stress should be pursued, e.g., pollen viability and the ability to set seed. Thus, the first step should be the development of reliable and informative screening methods before investing in crossing and breeding approaches. Although field evaluation in the target environment is ideal, many traits will necessarily require greenhouse or growth chamber screening protocols due to the difficulty of producing seed from wild relatives in traditional field plots. A small network of 6-8 sites for evaluation of germplasm for drought and heat tolerance, and the appropriate eco-physiological tools for phenotypic evaluation, should be developed.

A second approach is identification of potential abiotic stress-tolerant genotypes/traits through localization of wild populations in stress environments, e.g., high temperature zones, drought prone 
areas, etc., through agro-climatic analysis. The identification of wild populations will be facilitated by evaluation of previously identified ecological niches, the use of GIS data, and expert knowledge. For example, for drought in common bean, landraces from Chihuahua/Coahuila and the Yucatan in Mexico and Pernambuco in Brazil may be a good source of genes for introgression based on the drought stress experienced in these areas. Newly developed GIS tools will help to focus and orient germplasm evaluation since, for example, different types of drought stress (intermittent, terminal) can occur and bean species have developed different phenotypic responses to different types of stress. For example, the waxy cuticle is found only in the Coriacei, and the rugose seed testa only in the Rugosi. Are there unique genes in these sections, or are there the same genes but silenced in the other sections? This is an area where genomics and sequencing approaches could contribute novel information about candidate genes for introgression. A third approach is high-throughput phenotyping approaches for traits in wild relatives that resemble those in cultivated common bean. Suitable candidates need to be investigated based on research in other species and based on available high-throughput phenotyping platforms. These approaches can then be used for selection of a set of wild relatives to focus on for introgression of novel traits into common bean. A preliminary set of possible sources of wild germplasm would include 10 wild common beans from Mesoamerica, Durango, and Nueva Granada, 10 interspecific common bean breeding lines, 5 tepary beans, and 5 Lima beans of the Andean and Sieva types, for a total of 30 sources for introgression into common bean. This number would be feasible for evaluation and trait introgression while yielding significant genetic diversity.

Genetic analysis, as well as breeding and basic research approaches, will require effective transformation and hybridization technologies. Transformation methods for common bean have been developed (Rech et al., 2008 [147]), but require higher efficiency in order to support their widespread use which is the focus of a recently awarded USDA-NIFA grant. Thus, either tepary transformation with inter-specific $P$. vulgaris $\times P$. acutifolius hybridization needs to be optimized, or common bean transformation needs to be considered as a major goal of research efforts. Thus, we envision transformation as an important breeding tool for this work and for future breeding objectives. Hybridization will, however, remain the foundation for the introgression of traits from wild relatives. Two approaches for hybridization are envisioned, one a broad-based crossing and screening method using large numbers of crosses on large numbers of wild relatives and recurrent parents, in order to identify combining ability. Since combining ability for these wide crosses is unknown, this approach will allow a greater probability of success. For example, in the secondary gene pool of common bean, it may be possible to introgress traits from $P$. costaricensis, and for Lima bean from P. maculatifolius. A second hybridization alternative involves the focus on a small number of carefully selected wild relatives for a specific trait, based on phenotypic analysis, with a small set of selected common bean germplasm. Pedigree analysis can be used to select genotypes in cultivated common bean that have broad general combining ability, and would therefore have a higher probability of success.

The inbred backcross method will likely be the most effective method for introgressing traits of interest since abiotic stress tolerance is usually under complex genetic control. Although the advanced backcross method has previously been shown to be effective, it is a risky approach and labor intensive. The use of wild relatives will require investment in developing "best" breeding methods that should incorporate both classical breeding methods and genomic approaches. Thus, novel tools should be investigated to facilitate breeding progress. A well-saturated genetic map could, for example, be used for 
both selection of specific loci and for rapid restoration of the recurrent parent's genetic background using marker technologies such as SNPs.

The second alternative approach is to use more accessible traits (as compared to direct use of wild relatives) in existing inter-specific lines or in germplasm with wild genotype introgressions (Approach 2 in Figure 3). A few collaborating institutions have already developed germplasm that can be readily introgressed into cultivated common bean types, including traits for bruchid resistance, cold, heat, and drought tolerance. Work with this germplasm, along with other readily applicable approaches (in grey background color in Figure 3), will be initiated by the participating collaborators in order to ensure progress in the overall objectives of this research. In addition to abiotic stress tolerance, unique diversity for disease resistance traits are also available in wild and closely related species germplasm. Because disease resistance genes in common bean are often reported to be found in clusters, it will be worthwhile assembling a set of $P$. coccineus and $P$. dumosus that have been reported to have resistance to a specific disease. This set of accessions could be systematically screened with highly virulent strains of other diseases to attempt to identify novel sources of resistance that could be introgressed into common bean.

\section{Conclusions}

Sufficient background information has been developed to expedite the introgression of CWR traits for common bean improvement. However, gaps in knowledge need to be addressed in order to facilitate the effectiveness in breeding wild relatives. There is a need to develop improved phenotyping approaches for identifying traits related to stress tolerance in wild relatives. This represents a challenge that requires focused attention right from the beginning of future efforts. Thus, both low and high throughput evaluation methods for drought and heat need to be developed with associated or correlated traits, e.g., root, photosynthetic, and seed- and pod-formation traits. Appropriate testing environments need to be defined for both field and greenhouse/growth chamber evaluation of abiotic stress-related traits. Effective transformation methods for common bean need to be developed that are repeatable, effective, and efficient. Genomic methods need to be developed that can be used to identify the wild genome during the breeding program. Decision-making protocols need to be assembled to determine when and how to apply genomic tools to the breeding process. Approaches to breeding, such as breeding for specific market classes or for incorporation of a specific trait regardless of market class, need to be considered. Regions transmissible from sister species or wild relatives will be molecularly identified and characterized, versus those regions that are difficult to transfer into common bean. In terms of hybridization, a set of effective parents, for wild crosses/interspecific crosses, and their corresponding wild relative genotypes, will be assembled in order to facilitate future breeding efforts. Potential constraints to these approaches include the lack of passport information for many of these accessions, long generation time for seed increase, and limited seed supplies. Research efforts in filling these gaps in knowledge or techniques will facilitate progress in the introgression from wild relatives.

This research effort requires a wide range of expertise, including systematics, botany, breeding, genetics, and molecular biology. This research will also require a multi-year effort to achieve the goals and an organizational structure like that of the USAID, Pulse CRSP or USDA BeanCap to coordinate activities and share information among research teams. As a result of this research direction, a number of 
valuable resources and tools will be generated. These include characterized germplasm derived from wild relatives, germplasm lines with novel traits for release and use in breeding programs, genotypic information on wild accessions, structured populations (e.g., NILs, bi-parental populations), advanced populations with wild relative introgressions, and associated markers or QTLs for drought, heat, and potentially disease-related traits.

\section{Acknowledgements}

We would like to acknowledge the Global Crop Diversity Trust for convening the bean crop wild relative expert workshop through the initiative "Adapting agriculture to climate change: a global initiative to collect, conserve and use crop wild relatives," which is funded by the government of Norway. The contribution of the following workshop participants is also acknowledged: Jorge Acosta Gallegos, INIFAP, Mexico; Sarah Ayling, TGAC, UK; Stephen Beebe, CIAT, Colombia; Kirstin Bett, University of Saskatchewan, Canada; Nora Castaneda Alvarez, CIAT, Colombia; Alfonso Delgado-Salinas UNAM, Mexico; Paul Gepts, University of California at Davis, USA; Luigi Guarino, GCDT, Italy; Elcio Guimaraes, CIAT, Colombia; Alfredo Herrera-Estrella, Laboratorio Nacional de Genomica para la Biodiversidad, Mexico; Colin Khoury, CIAT, Colombia; Phillip Miklas, USDA, USA; Peter Pauls, Guelph University, Canada; Bodo Raatz, CIAT, Colombia; Julian Ramirez-Villegas, CIAT, Colombia; Shree Singh, University of Idaho, USA; Joe Tohme, CIAT, Colombia; and Carlos Urrea, University of Nebraska, USA. One of us (DGD) fully acknowledges Missouri Botanical Garden Press for granting permission to quote a sentence from the landmark book by Alan Graham [31].

\section{References}

1. USDA. National Agricultural Statistics Service (NASS). Crops and Plants [Online]; USDA-NASS: Washington, DC, USA, 2012. Available online: http://www.nass.usda.gov/ (accessed on 6 May 2013).

2. Palomino, V.R. Bayesian Analysis of a Linear Mixed Model to Measure the Impact of Climate Change on Yield of Common Bean for the Year 2030 Worldwide. Master's Thesis, University of Puerto Rico, Mayaguez, Puerto Rico, 2012.

3. Acosta-Gallegos, J.A.; Kelly, J.D.; Gepts, P. Prebreeding in common bean and use of genetic diversity from wild germplasm. Crop Sci. 2007, 47, S44-S49.

4. Rowlands, D.; Frame, D.J.; Ackerley, D.; Aina, T.; Booth, B.B.B.; Christensen, C.; Collins, M.; Faull, N.; Forest, C.E.; Grandey, B.S.; et al. Broad range of 2050 warming from an observationally constrained large climate model ensemble. Nat. Geosci. 2012, 5, 256-260.

5. Intergovernmental Panel on Climate Change (IPCC). Climate Change 2007: The Physical Science Basis. Contribution of Working Group I to the Fourth Assessment Report of the Intergovernmental Panel on Climate Change; Solomon, S., Qin, D., Manning, M., Chen, Z., Marquis, M., Averyt, K.B., Tignor, M., Miller, H.L., Eds.; Cambridge University Press: Cambridge, UK, 2007.

6. Beebe, S.; Ramirez, J.; Jarvis, A.; Rao, I.M.; Mosquera, G.; Bueno, J.M.; Blair, M.W. Genetic Improvement of Common beans and the Challenges of Climate Change. In Crop Adaptation to Climate Change; Yadav, S.S., Redden, R.J., Hatfield, J.L., Lotze-Campen, H., Hall, A.E., Eds.; Wiley-Blackwell: Chichester, UK, 2012; pp. 356-369. 
7. Singh, S.P.; Terán, H.; Lema, M.; Webster, D.M.; Strausbaugh, C.A.; Miklas, P.N.; Schwartz, H.F.; Brick, M.A. Seventy-five years of breeding dry bean of the Western USA. Crop Sci. 2007, 47, 1-9.

8. Shisanya, C.A. Improvement of drought adapted tepary bean (Phaseolus acutifolius A. Gray var. latifolius) yield through biological nitrogen fixation in semi-arid SE-Kenya. Eur. J. Agron. 2002, $16,13-24$.

9. Blair, M.W.; Iriarte, G.; Beebe, S. QTL analysis of yield traits in an advanced backcross population derived from a cultivated Andean $\times$ wild common bean (Phaseolus vulgaris L.) cross. Theor. Appl. Genet. 2006, 112, 1149-1163.

10. Koinange, E.M.K.; Singh, S.P.; Gepts, P. Genetic control of the domestication syndrome in common bean. Crop Sci. 1996, 36, 1037-1045.

11. Isely, D. Phaseolus. In The Jepson Manual-Higher Plants of California; Hickman, J.C., Ed.; University of California Press: Berkeley, CA, USA, 1993; p. 641.

12. Westphal, E. Pulses in Ethiopia: Their Taxonomy and Agricultural Significance; Centre for Agricultural Publishing and Documentation: Wageningen, The Netherlands, 1974; Volume 815, pp. 140-151.

13. Gepts, P. Phaseolin as an Evolutionary Marker. In Genetic Resources of Phaseolus Beans; Gepts, P., Ed.; Kluwer Academic Publishers: Dordrecht, The Netherlands, 1988; pp. 215-241.

14. Toro-Chica, O.; Ocampo, C.H.; Debouck, D.G. Phaseolin: Variability and reference materials in wild and cultivated common bean. Annu. Rep. Bean Improv. Coop. (USA) 2007, 50, 69-70.

15. Khairallah, M.M.; Sears, B.B.; Adams, M.W. Mitochondrial restriction fragment length polymorphisms in wild Phaseolus vulgaris L.: Insights on the domestication of the common bean. Theor. Appl. Genet. 1992, 84, 915-922.

16. Becerra-Velásquez, V.L.; Gepts, P. RFLP diversity of common bean (Phaseolus vulgaris) in its centres of origin. Genome 1994, 37, 256-263.

17. Bitocchi, E.; Nanni, L.; Bellucci, E.; Rossi, M.; Giardini, A.; Spagnoletti-Zeuli, P.; Logozzo, G.; Stougaard, J.; McClean, P.; Attene, G.; Papa, R. Mesoamerican origin of the common bean (Phaseolus vulgaris L.) is revealed by sequence data. Proc. Natl. Acad. Sci. USA 2012, 109, 788-796.

18. Nabhan, G.P. Native crop diversity in Aridoamerica: Conservation of regional gene pools. Econ. Bot. 1985, 39, 387-399.

19. Drewes, S.I. Prospección y colecta de germoplasma silvestre de Phaseolus vulgaris en la zona central de Argentina. Plant Genet. Resour. Newsl. 2008, 155, 9-14.

20. Becerra-Velásquez, V.; Paredes-Cárcomo, M.; Debouck, D.G. Genetic relationships of common bean (Phaseolus vulgaris L.) race Chile with wild Andean and Mesoamerican germplasm. Chilean J. Agric. Res. 2011, 71, 3-15.

21. Toro-Chica, O.; Tohme, J.; Debouck, D.G. Wild Bean (Phaseolus vulgaris L.): Description and Distribution; International Board for Plant Genetic Resources and International Center for Tropical Agriculture: Cali, Colombia, 1990; p. 106.

22. Debouck, D.G. Cahiers de Phaséologie: Section PHASEOLI; International Center for Tropical Agriculture (CIAT): Cali, Colombia, 2012; p. 172. Available online: http://www.ciat.cgiar.org/urg (accessed on 2 October 2012). 
23. Debouck, D.G.; Toro, O.; Paredes, O.M.; Johnson, W.C.; Gepts, P. Genetic diversity and ecological distribution of Phaseolus vulgaris (Fabaceae) in northwestern South America. Econ. Bot. 1993, 47, 408-423.

24. Gepts, P.; Osborn, T.C.; Rashka, K.; Bliss, F.A. Phaseolin protein variability in wild forms and landraces of the common bean (Phaseolus vulgaris L.): Evidence for multiple centers of domestication. Econ. Bot. 1986, 40, 451-468.

25. Koenig, R.L.; Singh, S.P.; Gepts, P. Novel phaseolin types in wild and cultivated common bean (Phaseolus vulgaris, Fabaceae). Econ. Bot. 1990, 44, 50-60.

26. Freyre, R.; Ríos, R.; Guzmán, L.; Debouck, D.G.; Gepts, P. Ecogeographic distribution of Phaseolus spp. (Fabaceae) in Bolivia. Econ. Bot. 1996, 50, 195-215.

27. Tohme, J.; González, D.O.; Beebe, S.; Duque, M.C. AFLP analysis of gene pools of a wild bean core collection. Crop Sci. 1996, 36, 1375-1384.

28. Chacón, S.M.I.; Pickersgill, B.; Debouck, D.G.; Arias, J.S. Phylogeographic analysis of the chloroplast DNA variation in wild common bean (Phaseolus vulgaris L.) in the Americas. Plant Syst. Evol. 2007, 266, 175-195.

29. Chacón, S.M.I.; Pickersgill, B.; Debouck, D.G. Domestication patterns in common bean (Phaseolus vulgaris L.) and the origin of the Mesoamerican and Andean cultivated races. Theor. Appl. Genet. 2005, 110, 432-444.

30. Kami, J.; Becerra-Velásquez, V.; Debouck, D.G.; Gepts, P. Identification of presumed ancestral DNA sequences of phaseolin in Phaseolus vulgaris. Proc. Natl. Acad. Sci. USA 1995, 92, 1101-1004.

31. Graham, A. Late Cretaceous and Cenozoic history of Latin American vegetation and terrestrial environments; Missouri Botanical Garden Press: St. Louis, MI, USA, 2010; p. 617.

32. Romero-Andreas, J.; Yandell, B.S.; Bliss, F.A. Bean arcelin. 1. Inheritance of a novel seed protein of Phaseolus vulgaris L. and its effect on seed composition. Theor. Appl. Genet. 1986, 72, $123-128$.

33. Acosta-Gallegos, J.A.; Quintero, C.; Vargas, J.; Toro, O.; Tohme, J.; Cardona, C. A new variant of arcelin in wild common bean, Phaseolus vulgaris L., from southern Mexico. Genet. Resour. Crop Evol. 1998, 45, 235-242.

34. Osborn, T.C.; Blake, T.; Gepts, P.; Bliss, F.A. Bean arcelin. 2. Genetic variation, inheritance and linkage relationships of a novel seed protein of Phaseolus vulgaris L. Theor. Appl. Genet. 1986, 71, $847-855$.

35. Lynch, J.; González, A.; Tohme, J.M.; Garcia, J.A. Variation in characters related to leaf photosynthesis in wild bean populations. Crop Sci. 1992, 32, 633-640.

36. González, A.; Lynch, J.; Tohme, J.M.; Beebe, S.E.; Macchiavelli, R.E. Characters related to leaf photosynthesis in wild populations and landraces of common bean. Crop Sci. 1995, 35, $1468-1476$.

37. Acosta-Gallegos, J.A.; Aguilar Garzón, B.; Rodríguez-Guerra, R.; Mendoza Hernández, M.; Guzman-Maldonado, H.; Kelly, J.D. Seed yield of black seeded lines introgressed with wild Phaseolus vulgaris. Annu. Rep. Bean Improv. Coop. (USA) 2007, 50, 23-24. 
38. Tanksley, S.D.; Grandillo, S.; Fulton, T.M.; Zamir, D.; Eshed, Y.; Petiard, V.; López, J.; Beck-Bunn, T. Advanced backcross QTL analysis in a cross between an elite processing line of tomato and its wild relative L. pimpinellifolium. Theor. Appl. Genet. 1996, 92, 213-224.

39. Xiao, J.; Li, J.; Grandillo, S.; Nag-Ahn, S.; Yuan, L.; Tanksley, S.D.; McCouch, S.R. Identification of trait-improving quantitative trait loci alleles from a wild rice relative, Oryza rufipogon. Genetics 1998, 150, 899-909.

40. Berglund-Brücher, O.; Brücher, H. The South American wild bean (Phaseolus aborigineus Burk.) as ancestor of the common bean. Econ. Bot. 1976, 30, 257-272.

41. Gentry, H.S. Origin of the common bean, Phaseolus vulgaris L. Econ. Bot. 1969, 23, 55-69.

42. Miranda-Colín, S. Origen de Phaseolus vulgaris L. (Frijol común). Agrociencia 1967, 1, 99-109.

43. Heiser, C.B. Cultivated plants and cultural diffusion in nuclear America. Am. Anthropol. 1965, 67, 930-949.

44. Kaplan, L. Phaseolus: Diffusion and Centers of Origin. In Man across the Sea: Problems in Pre-Columbian Contacts; Riley, C.L., Kelley, J.C., Pennington, C.W., Randa, R.L., Eds.; University of Texas Press: Austin, TX, USA, 1971; pp. 416-427.

45. Kwak, M.; Kami, J.A.; Gepts, P. The putative Mesoamerican domestication center of Phaseolus vulgaris is located in the Lerma-Santiago basin of Mexico. Crop Sci. 2009, 49, 554-563.

46. Maréchal, R.; Mascherpa, J.; Stainier, F. Etude taxonomique d'un groupe complexe d'espèces des genres Phaseolus et Vigna. (Papilionaceae) sur la base de données morphologiques et polliniques, traitées par l'analyse informatique. Boissiera 1978, 28, 1-273.

47. Schmit, V.; du Jardin, P.; Baudoin, J.P.; Debouck, D.G. Use of chloroplast DNA polymorphisms for the phylogenetic study of seven Phaseolus taxa including P. vulgaris and P. coccineus. Theor. Appl. Genet. 1993, 87, 506-516.

48. Delgado-Salinas, A.O.; Turley, T.; Richman, A.; Lavin, M. Phylogenetic analysis of the cultivated and wild species of Phaseolus (Fabaceae). Syst. Bot. 1999, 24, 438-460.

49. Delgado-Salinas, A.; Bibler R.; Lavin, M. Phylogeny of the genus Phaseolus (Leguminosae): A recent diversification in an ancient landscape. Syst. Bot. 2006, 31, 779-791.

50. Freytag, G.F.; Debouck, D.G. Taxonomy, distribution, and ecology of the genus Phaseolus (Leguminosae-Papilionoideae) in North America, Mexico and Central America. SIDA Bot. Misc. 2002, 23, 1-300.

51. Schmit, V.; Debouck, D.G. Observations on the origin of Phaseolus polyanthus Greenman. Econ. Bot. 1991, 45, 345-364.

52. Neill, D.A.; Klitgaard, B.B.; Lewis, G.P. Fabaceae. In Catalogue of the Vascular Plants of Ecuador; Jorgensen, P.M., León-Yánez, S., Eds.; Missouri Botanical Garden Press: St. Louis, MI, USA, 1999; pp. 468-484.

53. Debouck, D.G.; Smartt, J. Beans, Phaseolus spp. (Leguminosae-Papilionoideae). In Evolution of Crop Plants, 2nd ed.; Smartt, J., Simmonds, N.W., Eds.; Longman Scientific \& Technical: London, UK, 1995, pp. 287-294.

54. Araya-Villalobos, R.; González-Ugalde, W.G.; Camacho-Chacón, F.; Sánchez-Trejos, P.; Debouck, D.G. Observations on the geographic distribution, ecology and conservation status of several Phaseolus bean species in Costa Rica. Genet. Resour. Crop Evol. 2001, 48, 221-232. 
55. Freytag, G.F.; Debouck, D.G. Phaseolus costaricensis, a new wild bean species (Phaseolinae, Leguminosae) from Costa Rica and Panama, Central America. Novon 1996, 6, 157-163.

56. Ramírez-Delgadillo, R.; Delgado-Salinas, A. A new species of Phaseolus (Fabaceae) from west-central Mexico. SIDA 1999, 18, 637-646.

57. Delgado-Salinas, A.; Thulin, M.; Pasquet, R.; Weeden, N.; Lavin, M. Vigna (Leguminosae) sensu lato: The names and identities of the American segregate genera. Am. J. Bot. 2011, 98, 1694-1715.

58. Lackey, J.A. A review of generic concepts in American Phaseolinae (Fabaceae, Faboideae). Iselya 1983, 2, 21-64.

59. Lavin, M.; Herendeen, P.S.; Wojciechowski, M.F. Evolutionary rates analysis of Leguminosae implicates a rapid diversification of lineages during the Tertiary. Syst. Biol. 2005, 54, 575-594.

60. Gepts, P.; Papa, R.; Coulibaly, S.; González-Mejía, A.; Pasquet, R. Wild Legume Diversity and Domestication-Insights from Molecular Methods. In Wild Legumes; Oono, K., Ed.; National Institute of Biological Resources: Tsukuba, Japan, 2000; pp. 19-31.

61. Serrano-Serrano, M.L.; Hernández-Torres, J.; Castillo-Villamizar, G.; Debouck, D.; Chacón, M.I. Gene pools in wild Lima bean (Phaseolus lunatus L.) from the Americas: Evidences for an Andean origin and past migrations. Mol. Phylogenet. Evol. 2010, 54, 76-87.

62. Kuboyama, T.; Shintaku, Y.; Takeda, G. Hybrid plant of Phaseolus vulgaris L. and P. lunatus L. obtained by means of embryo rescue and confirmed by restriction endonuclease analysis of rDNA. Euphytica 1991, 54, 177-182.

63. Leonard, M.F.; Stephens, L.C.; Summers, W.L. Effect of maternal genotype on development of Phaseolus vulgaris L. x P. lunatus L. interspecific hybrid embryos. Euphytica 1987, 36, 327-332.

64. Kaplan, L.; Lynch, T. Phaseolus (Fabaceae) in archaeology: AMS radiocarbon dates and their significance for pre-Colombian agriculture. Econ. Bot. 1999, 53, 261-272.

65. Piperno, D.L. New Archaeobotanical Information on Early Cultivation and Plant Domestication Involving Microplant (Phytolith and Starch Grain) Remains. In Biodiversity in AgricultureDomestication, Evolution, and Sustainability; Gepts, P., Famula, Th.R., Bettinger, R.L., Brush, S.B., Damania, A.B., McGuire, P.E., Qualset, C.O., Eds.; Cambridge University Press: Cambridge, UK, 2012; pp. 136-159.

66. Piperno, D.L.; Dillehay, T.D. Starch grains on human teeth reveal early broad crop diet in northern Peru. Proc. Natl. Acad. Sci. USA 2008, 105, 19622-19627.

67. Ishimoto, M.; Suzuki, K.; Iwanaga, M.; Kikuchi, F.; Kitamura, K. Variation of seed-Amylase inhibitors in the common bean. Theor. Appl. Genet. 1995, 90, 425-429.

68. Seigler, D.S.; Maslin, B.R.; Conn, E.E. Cyanogenesis in the Leguminosae. In Advances in Legume Biology, Monographs in Systematic Botany from the Missouri Botanical Garden; Stirton, C.H., Zarucchi, J.L., Eds.; Missouri Botanical Garden: St. Louis, MO, USA, 1989; Volume 29, pp. 645-672.

69. Shreve, F.; Wiggins, I.L. Vegetation and Flora of the Sonoran Desert; Stanford University Press: Stanford, CA, USA, 1964; Volume 1, p. 840.

70. Balasubramanian, P.; Ahmad, F.; Vandenberg, A.; Hucl, P.J. Barriers to interspecific hybridization of common bean with Phaseolus angustissimus A. Gray and P. filiformis Bentham. J. Genet. Breed. 2005, 59, 321-328. 
71. Maréchal, R.; Baudoin, J.P. Observations sur quelques hybrids dans le genre Phaseolus IV. L'hybride Phaseolus vulgaris $\times$ Phaseolus filiformis. Bull. Rech. Agron. Gembloux. 1978, 13, 233-240.

72. Bayuelo-Jiménez, J.; Debouck, D.G.; Lynch, J. Salinity tolerance in Phaseolus species during early vegetative growth. Crop Sci. 2002, 42, 2184-2192.

73. Buhrow, R. The wild beans of southwestern North America. Desert Plants 1983, 5, 67-88.

74. Muñoz, L.C.; Blair, M.W.; Duque, M.C.; Tohme, J.; Roca, W. Introgression in common bean $\times$ tepary bean interspecific congruity-backcross lines as measured by AFLP markers. Crop Sci. 2004, 44, 637-645.

75. Lin, T.Y.; Markhart, A.H. Phaseolus acutifolius A. Gray is more heat tolerant than P. vulgaris L. in the absence of water stress. Crop Sci. 1996, 36, 110-114.

76. Miklas, P.N.; Rosas, J.C.; Beaver, J.S.; Telek, L.; Freytag, G.F. Field performance of select tepary bean germplasm in the Tropics. Crop Sci. 1994, 34, 1639-1644.

77. Brücher, H. The Wild Ancestor of Phaseolus vulgaris in South America. In Genetic Resources of Phaseolus Beans; Gepts, P., Ed.; Kluwer Academic Publishers: Dordrecht, The Netherlands, 1988; pp. 185-214.

78. Singh, S.P.; Terán, H.; Schwartz, H.; Otto, K.; Lema, M. White mold-resistant interspecific common bean germplasm lines VCW 54 and VCW 55. J. Plant Regist. 2009, 3, 191-197.

79. Ramírez-Villegas, J.; Khoury, C.; Jarvis, A.; Debouck, D.G.; Guarino, L. A gap analysis methodology for collecting crop genepools: A case study with Phaseolus beans. PLoS One 2010, 5 , $1-18$.

80. Vázquez-García, J.A.; Cuevas-Guzmán, R.; Cochrane, T.S.; Iltis, H.H.; Santana-Michel, F.J.; Guzmán-Hernández, L. Flora de Manantlán. SIDA Bot. Misc. 1995, 13, 1-312.

81. Tanksley, S.D.; McCouch, S.R. Seed banks and molecular maps: Unlocking genetic potential from the wild. Science 1997, 277, 1063-1066.

82. Beebe, S.; Rengifo, J.; Gaitan, E.; Duque, M.C.; Tohme, J. Diversity and origin of Andean landraces of common bean. Crop Sci. 2001, 41, 854-862.

83. Bitocchi, E.; Bellucci, E.; Giardini, A.; Rau, D.; Rodriguez, M.; Biagetti, E.; Santilocchi, R.; Spagnoletti Zeuli, P.; Gioia, T.; Logozzo, G.; et al. Molecular analysis of the parallel domestication of the common bean (Phaseolus vulgaris) in Mesoamerica and the Andes. New Phytol. 2012, doi:10.1111/j.1469-8137.2012.04377.x.

84. Gepts, P.; Debouck, D.G. Origin, Domestication, and Evolution of the Common Bean (Phaseolus vulgaris L.). In Common Beans: Research for Crop Improvement; Schoonhoven, A.V., Ed.; Commonwealth Agricultural Bureaux International: Wallingford, UK, 1991; pp. 7-53.

85. Acevedo, M.; Steadman, J.R.; Rosas, J.C.; Venegas, J. Coevolution of the bean rust pathogen Uromyces appendiculatus with its wild, weedy and domesticated hosts (Phaseolus spp.) at a center of diversity. Annu. Rep. Bean Improv. Coop. (USA) 2008, 51, 22-23.

86. Acevedo, M.; Steadman, J.R.; Rosas, J.C.; Venegas, J. Characterization of virulence diversity of the bean rust pathogen Uromyces appendiculatus in wild bean populations as a tool for effective resistance gene deployment. Annu. Rep. Bean Improv. Coop. (USA) 2005, 48, 132-133. 
87. Keneni, G.; Bekele, E.; Getu, E.; Imtiaz, M.; Damte, T.; Mulatu, B.; Dagne, K. Breeding food legumes for resistance to storage insect pests: potential and limitations. Sustainability 2011, 3, 1399-1415.

88. Osborn, T.C.; Alexander, D.C.; Sun, S.M.; Cardona, C.; Bliss, F.A. Insecticidal activity and lectin homology of arcelin seed protein. Science 1988, 240, 207-210.

89. Osborn, T.C.; Hartweck, L.M.; Harmsen, R.H.; Vogelzang, R.D.; Kmiecik, K.A.; Bliss, F.A. Registration of Phaseolus vulgaris genetic stocks with altered seed protein compositions. Crop Sci. 2003, 43, 1570-1571.

90. Kornegay, J.; Cardona, C.; Posso, C.E. Inheritance of resistance to Mexican bean weevil in common bean determined by bioassay and biochemical tests. Crop Sci. 1993, 33, 589-594.

91. Beaver, J.S.; Zapata, M.; Alameda, M.; Porch, T.G. Registration of PR0401-259 and PR0650-31 dry bean germplasm lines. J. Plant Regist. 2012, 6, 81-84.

92. Acevedo, M.; Steadman, J.R.; Rosas, J.C.; Venegas, J. New sources of resistance to bean rust and implications for host-pathogen coevolution. Annu. Rep. Bean Improv. Coop. (USA) 2006, 49 , 77-78.

93. Mkwaila, W.; Terpstra, K.A.; Ender, M.; Kelly, J.D. Identification of QTL for agronomic traits and resistance to white mold in wild and landrace germplasm of common bean. Plant Breed. 2011, 130, 665-672.

94. Kelly, J.; Long, B.; Blakely, N.; Terpstra, K. Dry bean yield trials, 2004. Available online: http://www.psm.msu.edu/VarietyTrials/Acrobat/04_DryBean_Report.pdf (accessed on 6 May 2013).

95. Wright, E.M.; Kelly, J.D. Mapping QTL for seed yield and canning quality following processing of black bean (Phaseolus vulgaris L.). Euphytica 2011, 179, 471-484.

96. Ferwerda, F.H.; Bassett, M.J. Barriers to interspecific hybridization in crosses between Phaseolus coccineus L. (G35172) and Phaseolus vulgaris L. Annu. Rep. Bean Improv. Coop. (USA) 2000, 43, 21-22.

97. Singh, S.P.; Gutiérrez, J.A. Geographical distribution of the $D L_{1}$ and $D L_{2}$ genes causing hybrid dwarfism in Phaseolus vulgaris L., their association with seed size, and their significance to breeding. Euphytica 1984, 33, 337-345.

98. Acevedo, M.; Steadman, J.R.; Rosas, J.C. Uromyces appendiculatus in Honduras: Pathogen diversity and host resistance screening. Plant Dis. 2012. Available online: http:// apsjournals.apsnet.org/doi/pdf/10.1094/PDIS-02-12-0169-RE (accessed on 6 May 2013).

99. Singh, S.P.; Terán, H.; Beaver, J.S. Scarlet runner bean germplasm accessions G 35006 and G 35172 possess resistance to multiple diseases of common bean. Annu. Rep. Bean Improv. Coop. (USA) 2009, 52, 20-21.

100. Osorno, J.M.; Muñoz, C.G.; Beaver, J.S.; Ferwerda, F.H.; Bassett, M.J.; Miklas, P.N.; Olczyk, T.; Bussey, B. Two genes from Phaseolus coccineus confer resistance to Bean Golden Yellow Mosaic Virus in common bean. J. Am. Soc. Hort. Sci. 2007, 132, 530-533.

101. Schwartz, H.F.; Otto, K.; Terán, H.; Lema, M. Inheritance of white mold resistance in Phaseolus vulgaris $\times$ P. coccineus crosses. Plant Dis. 2006, 90, 1167-1170. 
102. McCoy, S.; Higgins, B.; Steadman, J.R. Use of multi site screening to identify and verify partial resistance to white mold in common bean in 2011. Annu. Rep. Bean Improv. Coop. (USA) 2012 , $55,153-154$.

103. Wilkinson, R.E. Incorporation of Phaseolus coccineus germplasm may facilitate production of high yielding P. vulgaris lines. Annu. Rep. Bean Improv. Coop. (USA) 1983, 26, 28-29.

104. Miklas, P.N.; Zapata, M.; Beaver, J.S.; Grafton, K.F. Registration of four dry bean germplasms resistant to common bacterial blight: ICB-3, ICB-6, ICB-8 and ICB-10. Crop Sci. 1999, 39, 594.

105. Schmit, V.; Baudoin, J.P. Screening for resistance to Ascochyta blight in populations of Phaseolus coccineus L. and P. polyanthus Greenman. Field Crops Res. 1992, 30, 155-165.

106. Mahuku, G.S.; Jara, C.E.; Cajiao, C.; Beebe, S. Sources of resistance to Colletotrichum lindemuthianum in the secondary gene pool of Phaseolus vulgaris and in crosses of primary and secondary gene pools. Plant Dis. 2002, 86, 1383-1387.

107. Freytag, G.F.; Bassett, M.J.; Zapata, M. Registration of XR-235-1-1 bean germplasm. Crop Sci. 1982, 22, 1268-1269.

108. Zapata, M.; Freytag, G.; Wilkinson, R. Release of five common bean germplasm lines resistant to common bacterial blight W-BB-11, W-BB-20-1, W-BB-35, W-BB-52, and W-BB-56. J. Agric. Univ. Puerto Rico 2004, 88, 91-95.

109. Beaver, J.S.; Porch, T.G.; Zapata, M. Registration of 'Verano' white bean. J. Plant Regist. 2008, 2, 187-189.

110. Ferwerda, F.H. The Investigation of Genetic Barriers to Interspecific Crosses between Phaseolus acutifolius A. Gray, Phaseolus coccineus L. and Phaseolus vulgaris L. and the Inheritance of Resistance to Bean Golden Mosaic Virus from P. coccineus L. Ph.D. Thesis, University of Florida, Gainsville, FL, USA, August 2001.

111. Koinange, E.M.K.; Gepts, P. Hybrid weakness in wild Phaseolus vulgaris L. J. Hered. 1982, 83, 135-139.

112. Butare, L.; Rao, I.; Lepoivre, P.; Polania, J.; Cajiao, C.; Cuasquer, J.; Beebe, S. New genetic sources of resistance in the genus Phaseolus to individual and combined aluminium toxicity and progressive soil drying stresses. Euphytica 2011, 181, 385-404.

113. Nabhan, G.P. Tepary beans: The effects of domestication on adaptation to arid environments. Arid Lands Nwsl. 1979, 10, 11-16.

114. Porch, T.G.; Ramirez, V.H.; Santana, D.; Harmsen, E.W. Evaluation of common bean for drought tolerance in Juana Diaz, Puerto Rico. J. Agron. Crop. Sci. 2009, 195, 328-334.

115. Federici, C.T.; Ehdaie, B.; Waines, J.D. Domesticated and wild tepary bean: Field performance with and without drought-stress. Agron. J. 1990, 82, 896-900.

116. Markhart, A.H. Comparative water relation of Phaseolus vulgaris L. and Phaseolus acutifolius Gray. J. Plant Physiol. 1985, 77, 113-117.

117. Bhardwaj, H.L.; Rangappa, M.; Hamama, A.A. Planting date and genotype effects on tepary bean productivity. HortScience 2002, 2, 317-318.

118. Thomas, C.V.; Manshardt, R.M.; Waines, J.G. Teparies as a source of useful traits for improving common beans. Desert Plants 1983, 5, 43-48. 
119. Ferwerda, F.H.; Bassett, M.J.; Beaver, J.S. Viability of seed of reciprocal interspecific crosses between Phaseolus vulgaris L. and Phaseolus acutifolius A. Grey. Annu. Rep. Bean Improv. Coop. (USA) 2003, 46, 29-30.

120. Pratt, R.C. Gene transfer between tepary and common bean. Desert Plants 1983, 5, 57-63.

121. Haghighi, K.R.; Ascher, P.D. Fertile, intermediate hybrids between Phaseolus vulgaris and P. acutifolius from congruity backcrossing. Sex. Plant Reprod. 1988, 1, 51-58.

122. Anderson, N.O.; Ascher, P.D.; Haghighi, K. Congruity backcrossing as a means of creating genetic variability in self pollinated crops: seed morphology of Phaseolus vulgaris L. and $P$. acutifolius A. Gray hybrids. Euphytica 1996, 87, 211-224.

123. Mejía-Jiménez, A.; Muñoz, C.; Jacobson, H.J.; Roca, W.M.; Singh, S.P. Interspecific hybridization between common and tepary beans: Increased hybrid embryo growth, fertility and efficiency of hybridization through recurrent and congruity backcrossing. Theor. Appl. Genet. 1994, 88, 324-331.

124. Singh, S.P.; Debouck, D.G.; Roca, W.W. Interspecific hybridization between Phaseolus vulgaris L. and P. parvifolius Freytag. Annu. Rep. Bean Improv. Coop. (USA) 1998, 4, 7-8.

125. Scott, M.E.; Michaels, T.E. Xanthomonas resistance of Phaseolus interspecific cross selections confirmed by field performance. HortScience 1992, 27, 348-350.

126. Singh, S.P.; Muñoz, C.G. Resistance to common bacterial blight among Phaseolus species and common bean improvement. Crop Sci. 1999, 39, 80-89.

127. McElroy, J.B. Breeding Dry Beans, Phaseolus vulgaris L., for Common Bacterial Blight Resistance Derived from Phaseolus acutifolius A. Gray. Ph.D. Thesis, Cornell University, Ithaca, NY, USA, 1985.

128. Mutlu, N.; Urrea, C.A.; Miklas, P.N.; Pastor-Corrales, M.A.; Steadman, J.R.; Lindgren, D.T.J.; Reiser, J.; Vidaver, A.K.; Coyne, D.P. Registration of common bacterial blight, rust and bean common mosaic resistant Great Northern common bean germplasm line ABC-Weihing. J. Plant Regist. 2008, 2, 53-55.

129. Mutlu, N.; Miklas, P.N.; Steadman, J.R.; Vidaver, A.M.; Lindgren, D.T.; Reiser, J.; Coyne, D.P.; Pator-Corrales, M.A. Registration of common bacterial blight resistant pinto bean germplasm line ABCP-8. Crop Sci. 2005, 45, 806-807.

130. Fourie, D.; Herselman, L. Application of molecular markers in breeding for bean common blight resistance in South Africa. Afr. Crop Sci. J. 2011, 19, 369-376.

131. Costa, J.G.C.; Rava, C.A. Linhagens de feijoeiro comum com fenótipos agronômicos favoráveis e resistência ao crestamento bacteriano comum e antracnose. Ciênc. Agrotec. Lavras. 2003, 27, 1176-1182.

132. Osorno, J.M.; Grafton, K.; Vanderwal, A.; Gegner, S. A new small red bean with improved resistance to common bacterial blight: Registration of 'Rio Rojo'. J. Plant Regist. 2013, 8, in press.

133. Kusolwa, P.M.; Myers, J.R. Seed storage proteins ARL2 and its variants from the APA locus of wild tepary bean G40199 confers resistance to Acanthoscellides obtectus when expressed in common beans. Afr. Crop Sci. J. 2011, 19, 255-265.

134. Miklas, P.N.; Schwartz, H.F.; Salgado, M.O.; Beaver, J.S. Reaction of select tepary bean to Ashy Stem Blight and Fusarium Wilt. HortScience 1998, 33, 136-139. 
135. Miklas, P.N.; Santiago, J. Reaction of select tepary bean to Bean Golden Mosaic Virus. HortScience 1996, 31, 430-432.

136. Pastor-Corrales, M.A.; Steadman, J.R.; Urrea, C.A.; Blair, M.W.; Venegas, J.P. The domesticated tepary bean accession G 40022 has broader resistance to the highly variable bean rust pathogen than the known rust resistance genes in common bean. Annu. Rep. Bean Improv. Coop. (USA) 2011, 54, 124-125.

137. Mogotsi, K.K. Phaseolus acutifolius A. Gray. In Plant Resources of Tropical Africa 1. Cereals and Pulses; Brink, M., Belay, G., Eds.; PROTA Foundation: Wageningen, The Netherlands, 2006; pp. 133-137.

138. Singh, S.P.; Debouck, D.G.; Roca, W.W. Successful interspecific hybridization between Phaseolus vulgaris L. and P. costaricensis Freytag \& Debouck. Annu. Rep. Bean Improv. Coop. (USA) 1997, 40, 40-41.

139. Singh, S.P.; Terán, H.; Schwartz, H.F.; Otto, K.; Debouck, D.G.; Roca, W.; Lema, M. White mold-resistant, interspecific common bean breeding line VRW 32 derived from Phaseolus costaricensis. J. Plant Regist. 2013, 7, 95-99.

140. Montero-Rojas, M.; Ortiz, M.; Beaver, J.S.; Siritunga, D. Genetic, morphological and cyanogen content evaluation of a new collection of Caribbean Lima bean (Phaseolus lunatus L.) landraces. Genet. Resour. Crop Evol. 2013, doi:10.1007/s10722-013-9989-9.

141. Hyten, D.L.; Song, Q.; Fickus, E.W.; Quigley, C.V.; Lim, J.-S.; Choi, I.-Y.; Hwang, E.-Y.; Pastor-Corrales, M.P.; Cregan, P.B. High-throughput SNP discovery and assay development in common bean. BMC Genomics 2010, 11, 475.

142. Phytozome. Available online: http://www.phytozome.net/commonbean (accessed on 6 May 2013).

143. Le, S.Q.; Durbin, R. SNP detection and genotyping from low-coverage sequencing data on multiple diploid samples. Genome Res. 2010, 21, 952-960.

144. Elshire, R.J.; Glaubitz, J.C.; Sun, Q.; Poland, J.A.; Kawamoto, K.; Buckler, E.S.; Mitchell, S.E. A robust, simple genotyping by sequencing (GBS) approach for high diversity species. PLoS One 2011, 6, e19379.

145. Kidd, J.M.; Graves, T.; Newman, T.; Fulton, R.; Hayden, H.S.; Malig, M.; Kallicki, J.; Kaul, R.; Wilson, R.K.; Eichler, E.E. A human genome structural variation sequencing resource reveals insights into mutation mechanisms. Cell 2011, 143, 837-847.

146. Cokus, S.J.; Feng, S.; Hang, X.; Chen, Z.; Merriman, B.; Haudenshcild, C.D.; Pradhan, S.; Nelson, S.F.; Pellegrini, M.; Jacobsen, S.E. Shotgun bisulphite sequencing of the Arabidopsis genome reveals DNA methylation patterning. Nature 2008, 452, 215-219.

147. Rech, E.L.; Vianna, G.R.; Aragão, F.J.L. High-efficiency transformation by biolistics of soybean, common bean and cotton transgenic plants. Nat. Protoc. 2008, 3, 410-418.

(C) 2013 by the authors; licensee MDPI, Basel, Switzerland. This article is an open access article distributed under the terms and conditions of the Creative Commons Attribution license (http://creativecommons.org/licenses/by/3.0/). 